\title{
Capacity and Modeling of Acid Blue 113 Dye Adsorption onto Chitosan Magnetized by $\mathrm{Fe} 2 \mathrm{O} 3$ Nanoparticles
}

\author{
Tariq Al-Musawi ( $\nabla$ tariqjwad@yahoo.com ) \\ Isra University https://orcid.org/0000-0001-9852-3122 \\ Nezamaddin Mengelizadeh \\ Larestan University of Medical Sciences
}

Orabi Shareef AL-Rawi

Isra University

Davoud Balarak

Zahedan University of Medical Sciences

\section{Research Article}

Keywords: Acid blue 113, Chitosan, Fe2O3 nanoparticles, Modeling, Adsorption study

Posted Date: May 10th, 2021

DOl: https://doi.org/10.21203/rs.3.rs-334767/v1

License: (c) This work is licensed under a Creative Commons Attribution 4.0 International License.

Read Full License

Version of Record: A version of this preprint was published at Journal of Polymers and the Environment on June 7th, 2021. See the published version at https://doi.org/10.1007/s10924-021-02200-8. 


\section{Capacity and modeling of acid blue 113 dye adsorption onto chitosan magnetized by $\mathrm{Fe}_{2} \mathrm{O}_{3}$ nanoparticles}

Tariq J. Al-Musawi ${ }^{1}$, Nezamaddin Mengelizadeh ${ }^{2}$, Orabi Shareef AL-Rawi ${ }^{1}$, Davoud Balarak ${ }^{3, *}$

${ }^{1}$ Department of Civil Engineering, Faculty of Engineering, Isra University, Amman, Jordan

${ }^{2}$ Research Center of Health, Safety and Environment, Department of Environmental Health

Engineering, Evaz Faculty of Health, Larestan University of Medical Sciences, Larestan, Iran.

${ }^{3}$ Department of Environmental Health, Health Promotion Research Center, Zahedan University of Medical Sciences, Zahedan, Iran.

* Corresponding author email: dbalarak2@gmail.com 


\section{Abstract}

A chitosan polymer was magnetized by coating with magnetite $\mathrm{Fe}_{2} \mathrm{O}_{3}$ nanoparticles, and the resultant material $\left(\mathrm{C}-\mathrm{Fe}_{2} \mathrm{O}_{3}\right)$ was first characterized through scanning electron microscopy equipped with energy-dispersive X-ray spectroscopy, transmission electron microscopy, atomic force microscopy, thermogravimetric, X-ray diffractometry, Fourier transform infrared spectroscopy, Brunauer-Emmett-Teller, and point of zero charge analyses. $\mathrm{C}-\mathrm{Fe}_{2} \mathrm{O}_{3}$ was then employed as a separable and efficient adsorptive agent to remove acid blue 113 (AB113) dye from aqueous solution. The removal efficiency was optimized at different environmental parameter values ( $\mathrm{pH}$ : 3-11, $\mathrm{C}-\mathrm{Fe}_{2} \mathrm{O}_{3}$ dose: $0.1-1 \mathrm{~g} / \mathrm{L}$, initial $\mathrm{AB} 113$ dye concentration: $10-100$ $\mathrm{mg} / \mathrm{L}$, adsorption time: 0-300 min, and temperature: $388-318 \mathrm{~K}$ ). Under optimum conditions, an AB113 dye removal efficiency of $99.68 \%$ was achieved. In addition, the effect of the presence of $\mathrm{NaCl}, \mathrm{NaNO}_{3}, \mathrm{Na}_{2} \mathrm{CO}_{3}$, and $\mathrm{MgSO}_{4}$ ions on the $\mathrm{AB} 113$ dye removal efficiency could be ranked as $\mathrm{NaCl}>\mathrm{NaNO}_{3}>\mathrm{MgSO}_{4}>\mathrm{Na}_{2} \mathrm{CO}_{3}$. The statistical analysis using the coefficient of determination, root mean square error, chi-square test, sum of squared errors, and average relative error showed that the Freundlich and pseudo-second-order equations were the best mathematical models for fitting the isothermal and kinetics data. Further kinetics analyses showed that the adsorption of $\mathrm{AB} 113$ molecules on $\mathrm{C}-\mathrm{Fe}_{2} \mathrm{O}_{3}$ active sites was dominated by the intraparticle diffusion process. Thermodynamic parameters indicated that the AB113 dye adsorption process was favorable, endothermic, and spontaneous. Furthermore, an increase in temperature had a positive impact on AB113 dye removal. The regeneration study confirmed the excellent shelf life of $\mathrm{C}-\mathrm{Fe}_{2} \mathrm{O}_{3}$, with only a slight loss in the removal efficiency $(<7 \%)$ being detected after six operational cycles of AB113 dye adsorption. Compared with other adsorbents, 
C- $\mathrm{Fe}_{2} \mathrm{O}_{3}$ was more effective for the adsorption of $\mathrm{AB} 113$ dye, with an adsorption uptake up to $128 \mathrm{mg} / \mathrm{g}$.

Keywords: Acid blue 113; Chitosan; $\mathrm{Fe}_{2} \mathrm{O}_{3}$ nanoparticles; Modeling; Adsorption study

\section{Introduction}

Currently, dye pollutants are among the most dangerous compounds that are pumped into the environment via the effluents of different factories, such as those for paper, textiles, paints, leather, and cosmetics (Wu et al., 2013; Elgin et al., 2008). Azo dyes are widely applied in various dyeing processes due to their high activity; thus, these types of dyes generally make up approximately $50-70 \%$ of the total dye quantity employed in industry (Shan et al., 2015; Bazrafshan et al., 2013; Giustetto et al., 2011). On the other hand, simple azo dyes (e.g., picric acid and anionic and cationic dyes) consist of hydroxyl groups in their structure and do not establish a strong bond with the texture of fabrics and linen fibers; thus, for dyeing, a large quantity of simple azo dyes are consumed (Crini et al., 2008; Balarak et al., 2020). Azo dyes contain natural and synthetic organic compounds and are characterized in nature as refractory and stable organic pollutants (Savic et al., 2014; Zhang et al., 2013). For example, acid blue 113 (AB113) dye has been selected as the target dye due to its wide application in industry, especially in the paints and textile industries. Furthermore, studies have shown that azo dyes have two types of auxochrome (-OH, $-\mathrm{NH}_{2}$, and $\left.\mathrm{NR}_{2}\right)$ and chromophore $(\mathrm{C}=\mathrm{C}, \mathrm{N}=\mathrm{N}$, and $\mathrm{C}=\mathrm{O})$ functional groups (Zhang et al., 2013; Eren et al., 2010). These two groups have a high tendency to attach to benzene and naphthalene rings that may be found in wastewater and, in some cases, can also be attached to aliphatic and heterocyclic groups, leading to the generation of hazardous byproducts (Sanghi et al., 2013; Huang et al., 2011; Ma et al., 2011; Li et al., 2010). In addition to their toxicity to humans, the presence of dyes in water bodies can disturb aquatic life via their 
ability to reduce the penetration of sunlight, which is essential for photosynthesis (Hao et al., 2013; Balarak et al., 2020). Thus, wastewater containing dyes must go through efficient purification processes prior to discharge to the environment. In reality, dyes cannot be lowered to the acceptable concentration via pretreatment or conventional methods (Crini et al., 2008 Anirudhan et al., 2009). Therefore, researchers are looking for advanced techniques to effectively remove these compounds prior to discharge into water bodies (Elgin et al., 2008; Wu et al., 2013).

Low portions of dye pollutants are removed by conventional treatment methods. Furthermore, some efficient methods have high costs (Baskaralingam et al., 2006; Balarak et al., 2020). Therefore, alternative techniques to traditional dye removal methods are still in demand. Currently, the efficient and low-cost method used for this purpose is separation by adsorption processes (Sillanpää et al., 2021; Balarak et al., 2016; Cheung et al., 2007). One of the most important operational and economic factors of adsorption treatment is the adsorbent used, as well as separating the spent adsorbents after treatment. To solve the separation problem and simultaneously increase the adsorption efficiency of the used adsorbent, the magnetization of used adsorbents is a promising method. Coating used adsorbents with magnetic nanoparticles has also been recommended because this modification method not only improves the removal efficiency but also improves the economic efficiency, environmental compatibility, mechanical strength, reusability and scalability of the magnetized adsorbents (Xua et al., 2012; Kyzas et al., 2013). In this direction, $\mathrm{Fe}_{2} \mathrm{O}_{3}$ nanoparticles have been widely used (Broujeni et al., 2018; Mittal et al., 2014). However, the use of pure magnetic particles also has a drawback, as these particles have a high tendency to agglomerate in aqueous solution. When these particles are combined 
with other materials, such as chitosan, the agglomeration mechanism is hampered (Kavitha et al., 2012).

Natural materials are welcomed and highly recommended for application as adsorptive treatment agents (Tabak et al., 2010). Chitosan is a natural hydrophilic and cationic biopolymer obtained by the removal of acetyl-chitin groups in an alkaline environment and has been extensively studied as an adsorbent to remove a variety of contaminants (e.g., heavy metals, antibiotics, and dyes) (Bazrafshan et al., 2013; Tabak et al., 2010; Gupta et al., 2005). Chitosan has low cytotoxicity and unique chemical properties; furthermore, chitosan is obtained from chitin, which is effortlessly attained from shrimp and crab shells (these are considered waste products of the seafood industry) (Tabak et al., 2010). Chitosan has two hydroxyl groups and one amino group in the glycosidic fraction and has a suitable matrix that allows fabrication with foreign particles (Xua et al., 2012). Because chitosan dissolves in acidic and aqueous solutions, there is no need to use hazardous organic solvents (Cheung et al., 2007; Khandanlou et al., 2013). Sun et al. used a chitosan/cellulose composite to adsorb lead ions from aqueous solutions (Sun et al., 2009). Furthermore, chitosan magnetized by $\mathrm{Fe}_{2} \mathrm{O}_{3}$ nanoparticles has also been employed for eradicating heavy metals from solutions (Chokami et al., 2017; Broujeni et al., 2018).

Through our review of previous research, it was found that very few studies have been performed on the removal of organic pollutants, such as dyes using chitosan magnetized by $\mathrm{Fe}_{2} \mathrm{O}_{3}$ nanoparticles (hereafter referred to as $\mathrm{C}-\mathrm{Fe}_{2} \mathrm{O}_{3}$ ). Therefore, the present study offers a comprehensive account of the application of $\mathrm{C}-\mathrm{Fe}_{2} \mathrm{O}_{3}$ as an efficient and recyclable adsorbent for the removal of $\mathrm{AB} 113$ dye from aqueous solutions. Initially, the surface and structural characterizations of used $\mathrm{C}-\mathrm{Fe}_{2} \mathrm{O}_{3}$ are obtained by advanced characterization analyses. The adsorption process of the $\mathrm{AB} 113$ dye and $\mathrm{C}-\mathrm{Fe}_{2} \mathrm{O}_{3}$ couple is reported with different 
environmental parameters. Isotherm and kinetics studies, which are the focus of this study, are conducted using linear and nonlinear models. The thermodynamics parameters are also determined. Finally, the recyclability of $\mathrm{C}-\mathrm{Fe}_{2} \mathrm{O}_{3}$ is evaluated in several $\mathrm{AB} 113$ dye adsorptiondesorption cycles.

\section{Materials and methods}

\subsection{Materials}

Chitosan with a chemical formula $\left(\mathrm{C}_{6} \mathrm{H}_{11} \mathrm{O}_{4} \mathrm{~N}\right)_{n}$ and purity of $98 \%$ was purchased from SigmaAldrich (Germany). Acetic acid ( $\geq 99.7 \%), \mathrm{FeCl}_{3} .6 \mathrm{H}_{2} \mathrm{O}$ ( $\left.\geq 98 \%\right), \mathrm{FeCl}_{2} .4 \mathrm{H}_{2} \mathrm{O}(\geq 99 \%), \mathrm{HCl}$ (36.5\%), and $\mathrm{NaOH}(\geq 98 \%)$ were purchased from Merck (Germany). In addition, a stock solution of AB113 dye (1000 mg/L) was bought from the Alvan Sabet factory (Hamadan, Iran).

\subsection{Preparation of $\mathrm{C}-\mathrm{Fe}_{2} \mathrm{O}_{3}$}

Initially, $2 \mathrm{~g}$ of chitosan was gradually dissolved in deionized water (100 mL) containing $2 \%$ acetic acid and magnetically stirred at $120 \mathrm{rpm}$ for $1 \mathrm{~h}$. To ensure the dissolution of all used chitosan quantities, the prepared chitosan solution was homogenized by means of ultrasonic waves for 20 min using an ultrasonic device (Sunshine ultrasonic cleaner, model SS6508T). A mixture of $\mathrm{FeCl}_{3} \cdot 6 \mathrm{H}_{2} \mathrm{O}(6.1 \mathrm{~g})$ with $\mathrm{FeCl}_{2} \cdot 4 \mathrm{H}_{2} \mathrm{O}(4.2 \mathrm{~g})$ at a molar ratio of 2:1 was mixed with the chitosan solution with the simultaneous dropwise addition of a $30 \% \mathrm{NaOH}$ solution (this process was carried out through the employment of a nitrogen gas stream at a temperature $\geq 70$ ${ }^{\circ} \mathrm{C}$, while being mixed at $1000 \mathrm{rpm}$ for $2 \mathrm{~h}$ ). Subsequently, the mixture was homogenized by ultrasonic waves for $20 \mathrm{~min}$. After that, the temperature of the homogenized mixture was increased to $90{ }^{\circ} \mathrm{C}$, and when reaching this temperature, the stirring process was further continued for $2 \mathrm{~h}$. Next, the resulting mixture was deoxygenated 4 times with distilled water and rinsed with ethanol. The supernatant $\left(\mathrm{C}-\mathrm{Fe}_{2} \mathrm{O}_{3}\right)$ was then collected in a container and 
neutralized. Afterward, a centrifuge (3600 rpm for $10 \mathrm{~min}$ ) was used to separate $\mathrm{C}-\mathrm{Fe}_{2} \mathrm{O}_{3}$ from the solution, followed by drying in an oven $\left(70{ }^{\circ} \mathrm{C}\right.$ for $\left.5 \mathrm{~h}\right)$. Eventually, after crushing and crystallization, $\mathrm{C}-\mathrm{Fe}_{2} \mathrm{O}_{3}$ was placed in a desiccator in the presence of a magnetic field for dehumidification.

\subsection{Characterization analyses}

Surface and structural characterizations of the $\mathrm{C}-\mathrm{Fe}_{2} \mathrm{O}_{3}$ sample were performed using XRD with a $\mathrm{Cu}$ Ka radiation source (ESCALAB250 Thermo Fisher), SEM (Model JSM6510LV, JEOL Ltd., Tokyo, Japan) connected with an EDX attachment (SEM/EDX), TEM (Philips CM120, Netherlands), FTIR spectroscopy (PerkinElmer, Spectrum GX), and UV-Vis spectrophotometry (DR5000, $\mathrm{HACH}$ ). The magnetization curves of $\mathrm{Fe}_{2} \mathrm{O}_{3}$ nanoparticles and $\mathrm{C}-\mathrm{Fe}_{2} \mathrm{O}_{3}$ were measured using a vibrating sample magnetometer (Lake Shore Cryotronics, 7407-S). The improvement in the thermal stability of chitosan after magnetization with $\mathrm{Fe}_{2} \mathrm{O}_{3}$ nanoparticles was determined using thermogravimetric analysis (TGA, TA Instruments SDT Q600, USA). The surface area and pore size were obtained by employing Brunauer-Emmett-Teller (BET) analyses. The changes in the topography of the $\mathrm{C}-\mathrm{Fe}_{2} \mathrm{O}_{3}$ surface due to $\mathrm{AB} 113$ dye adsorption were explored using atomic force microscopy (AFM, Nano Wizard II, JPK Germany). The $\mathrm{pH}_{\mathrm{pzc}}$

value of $\mathrm{C}-\mathrm{Fe}_{2} \mathrm{O}_{3}$ was evaluated using a previously reported methodolgy (Khodadadi et al., 2019). In addition, the magnetic properties of chitosan and $\mathrm{C}-\mathrm{Fe}_{2} \mathrm{O}_{3}$ were determined at ambient temperature using a vibrating-sample magnetometer (VSM, MDKB).

\subsection{Batch experiments}

The AB113 dye adsorption experiments were carried out in several $200 \mathrm{~mL}$ Erlenmeyer flakes with a dye solution of $100 \mathrm{~mL}$. AB113 dye removal by $\mathrm{C}-\mathrm{Fe}_{2} \mathrm{O}_{3}$ was optimized by varying the $\mathrm{pH}(3-11), \mathrm{C}-\mathrm{Fe}_{2} \mathrm{O}_{3}$ dose $(0.1-1 \mathrm{~g} / \mathrm{L})$, initial $\mathrm{AB} 113$ dye concentration $(10-100 \mathrm{mg} / \mathrm{L})$, 
adsorption time $(0-300 \mathrm{~min})$, and temperature $(388-318 \mathrm{~K})$. In addition, the effect of the presence of interference ions $\left(\mathrm{NaCl}, \mathrm{NaNO}_{3}, \mathrm{Na}_{2} \mathrm{CO}_{3}\right.$, and $\left.\mathrm{MgSO}_{4}\right)$ on the adsorptive performance of $\mathrm{C}-\mathrm{Fe}_{2} \mathrm{O}_{3}$ was examined. All flasks were placed in a shaker incubator at $120 \mathrm{rpm}$. Except for the thermodynamic experiments, which were performed from 288 to $318 \mathrm{~K}$, the flasks were maintained at room temperature $\left(25 \pm 2{ }^{\circ} \mathrm{C}\right)$ throughout the adsorption experiments. For the kinetic study, the experimental data of the analysis of the effects of the initial AB113 dye concentration on the $\mathrm{C}-\mathrm{Fe}_{2} \mathrm{O}_{3}$ adsorption capacity were used. Furthermore, for the isotherm study, an experiment was conducted to determine the relationship between the adsorption capacity of $\mathrm{C}-\mathrm{Fe}_{2} \mathrm{O}_{3}$ at equilibrium and the $\mathrm{AB} 113$ dye concentration. During the adsorption process, a $3 \mathrm{~mL}$ liquid sample was taken from each flask at regular adsorption time intervals and subjected to centrifugation at $1509 \mathrm{x}$ g for $15 \mathrm{~min}$. The concentration of $\mathrm{AB} 113$ dye in the separated supernatant was determined using a UV-Vis laboratory spectrophotometer (DR 5000, $\mathrm{HACH})$. From the determined AB113 dye concentrations, the dye removal efficiency $(R(\%))$ and adsorption capacity (or uptake) $\left(q_{t}\right)$ of $\mathrm{C}-\mathrm{Fe}_{2} \mathrm{O}_{3}$ for $\mathrm{AB} 113$ dye were calculated using Equations (1) and (2), respectively (Khodadadi et al., 2019; Mittal et al., 2014).

$R E(\%)=\frac{\left(C_{0}-C_{t}\right)}{C_{0}} \times 100$

$q_{t}=\frac{\left(C_{0}-C_{t}\right)}{M / V}$

where $C_{0}$ is the initial AB113 dye concentration $(\mathrm{mg} / \mathrm{L}), C_{t}$ is the $\mathrm{AB} 113$ dye concentration after a specific time of the adsorption process $(t, \min ), M$ is the $\mathrm{C}-\mathrm{Fe}_{2} \mathrm{O}_{3}$ mass $(\mathrm{g})$, and $V$ is the volume of the $\mathrm{AB} 113$ dye solution $(\mathrm{L})(100 \mathrm{~mL})$. Note that the AB113 dye concentration and $\mathrm{C}-$ $\mathrm{Fe}_{2} \mathrm{O}_{3}$ adsorption capacity at equilibrium time are denoted in Equation (1) by $C_{e}(\mathrm{mg} / \mathrm{L})$ and $q_{e}$ $(\mathrm{mg} / \mathrm{g})$, respectively. 


\subsection{Error function analysis}

The purpose of conducting the error function analysis in the present study is to assess the compatibility of the theoretical isotherm and kinetics model with the experimental data. However, the experimental data were fitted with both linear and nonlinear equations of these models. Depending on the values of the coefficient of determination $\left(R^{2}\right)$, sum of squared errors (SSE) (Equation 3), root mean square error (RMSE) (Equation 4), chi-square test $\left(x^{2}\right)$ (Equation 5), and average relative error (ARE) (Equation 6), the most appropriate model for the experimental data was evaluated (Hu et al., 2015; Fontana et al., 2016). sum of squared errors $(S S E)=\sum_{i=1}^{n}\left(q_{\text {e exp }}-q_{\text {e cal }}\right)^{2}$

root mean square error $(R M S E)=\sqrt{\frac{1}{n-p} \sum_{i=1}^{n}\left(q_{\text {e exp }}-q_{\text {e cal }}\right)^{2}}$

chi-square test $\left(x^{2}\right)=\sum_{i=1}^{n}\left[\frac{\left(q_{\text {eexp }}-q_{\text {ecal }}\right)^{2}}{q_{\text {ecal }}}\right]$

average relative error $(A R E)=\frac{100}{n} \sum_{i=1}^{n}\left[\frac{q_{e \text { exp }}-q_{e c a l}}{q_{e \text { exp }}}\right]$

where $q_{e \text { exp }}$ is the experimental uptake determined based on Equation (2), and $q_{e c a l}$ is the calculated uptake determined from the application of the relevant model with the experimental data.

\section{Results and discussion}

\subsection{Characterization analyses}

BET analysis revealed that the surface area of $\mathrm{C}-\mathrm{Fe}_{2} \mathrm{O}_{3}$ is $112.9 \mathrm{~m}^{2} / \mathrm{g}$. In addition, the pore volume and mean diameter are $0.286 \mathrm{~cm}^{3} / \mathrm{g}$ and $17.2 \mathrm{~nm}$, respectively. Compared with the documented surface area value for a sample of pure chitosan $\left(91.4 \mathrm{~m}^{2} / \mathrm{g}\right.$ ) (Broujeni et al., 2018), it can be concluded that the coating of chitosan with $\mathrm{Fe}_{2} \mathrm{O}_{3}$ significantly enhances the surface 
area of this polymer. Notably, solid materials with a large surface area are favorable as adsorbents in adsorption treatment systems, as this parameter reflects the number of adsorption sites for pollutant molecules.

The SEM images of the $\mathrm{C}-\mathrm{Fe}_{2} \mathrm{O}_{3}$ before and after $\mathrm{AB} 113$ dye adsorption are shown in Fig. 1a and $1 \mathrm{~b}$, respectively. It appears that $\mathrm{C}-\mathrm{Fe}_{2} \mathrm{O}_{3}$ exhibits an extremely rough surface and porous structure, and many fragments are randomly spread onto this material (Fig. 1a). In reality, these morphological characterizations of $\mathrm{C}-\mathrm{Fe}_{2} \mathrm{O}_{3}$ indicate that this adsorbent has a large reaction area for adhering AB113 dye molecules. After AB113 dye adsorption (Fig. 1b), the surface and pores of $\mathrm{C}-\mathrm{Fe}_{2} \mathrm{O}_{3}$ are completely covered, which provides an indication about the ability of $\mathrm{C}-\mathrm{Fe}_{2} \mathrm{O}_{3}$ to adsorb AB113 molecules. The EDX analysis (equipped on an SEM device) performed on the C$\mathrm{Fe}_{2} \mathrm{O}_{3}$ sample shows the presence of $\mathrm{C}(39.95 \%), \mathrm{N}(11.31 \%), \mathrm{O}(45.72 \%)$, and $\mathrm{Fe}(3.02 \%) . \mathrm{C}$ and $\mathrm{N}$ are essential elements in the structure of chitosan (Cheung et al., 2007; Xua et al., 2012). On the other hand, the presence of $\mathrm{Fe}$ and $\mathrm{O}$ in the structure of $\mathrm{C}-\mathrm{Fe}_{2} \mathrm{O}_{3}$ is the result of the successful magnetizing process of chitosan by $\mathrm{Fe}_{2} \mathrm{O}_{3}$ nanoparticles.

Fig. 1c is a TEM image of the $\mathrm{C}-\mathrm{Fe}_{2} \mathrm{O}_{3}$ sample taken at a scale of $50 \mathrm{~nm}$. From this figure, it is perceived that the $\mathrm{Fe}_{2} \mathrm{O}_{3}$ nanoparticles are entrenched into the chitosan structure. where the lightcolored area belongs to chitosan and the dark spots represent the $\mathrm{Fe}_{2} \mathrm{O}_{3}$ nanoparticles. Furthermore, the TEM image reveals that the synthesized $\mathrm{C}-\mathrm{Fe}_{2} \mathrm{O}_{3}$ particles are almost spherical in shape, and no aggregation is observed between these particles. The size of the $\mathrm{C}-\mathrm{Fe}_{2} \mathrm{O}_{3}$ particles is approximately $50 \mathrm{~nm}$, as also confirmed by XRD.

The X-ray diffraction pattern of $\mathrm{C}-\mathrm{Fe}_{2} \mathrm{O}_{3}$ is depicted in Fig. 1d. The $\mathrm{C}-\mathrm{Fe}_{2} \mathrm{O}_{3}$ has major peaks at $2 \theta=63^{\circ}$ and $36^{\circ}$. The average size of $\mathrm{C}-\mathrm{Fe}_{2} \mathrm{O}_{3}$ is calculated by substituting the main peak phase 
value of the $\mathrm{C}-\mathrm{Fe}_{2} \mathrm{O}_{3}$ in the Scherrer formula (Equation 7). Based on this equation, the synthesized nanoparticle size in the main peak at $2 \theta=36^{\circ}$ (with an intensity of approximately 120 a.u.) is determined to be $35.5 \mathrm{~nm}$.

$D=\frac{K \lambda}{\beta \cos \theta}$

where $D$ is the mean size of $\mathrm{C}-\mathrm{Fe}_{2} \mathrm{O}_{3}, K$ is a fixed number equal to $0.89, \lambda$ is the wavelength of the $\mathrm{Cu}-\mathrm{K} \alpha$ radiation $(\mathrm{nm}), \beta$ is the width of the main peak at half its intensity (radians) and $\theta$ (diffraction angle, radians) is the peak position in the XRD pattern (Hilal et al., 2012).
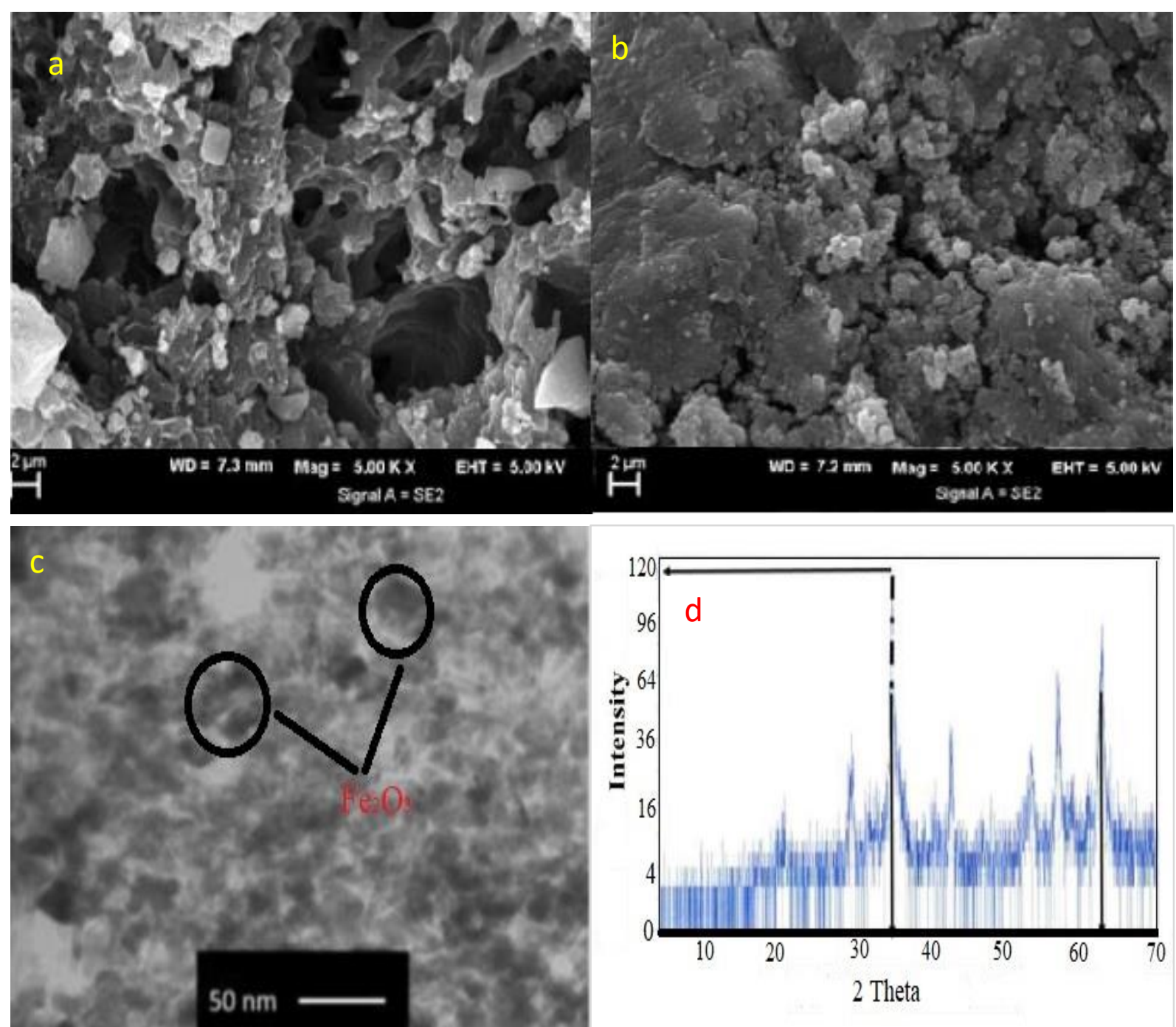
Fig. 1. SEM images of $\mathrm{C}-\mathrm{Fe}_{2} \mathrm{O}_{3}$ before (a) and after (b) AB113 adsorption. TEM image of $\mathrm{C}-$ $\mathrm{Fe}_{2} \mathrm{O}_{3}$ (c). X-ray diffraction pattern of $\mathrm{C}-\mathrm{Fe}_{2} \mathrm{O}_{3}(\mathrm{~d})$.

Fig. 2 shows the 2D and 3D AFM images, which are used to compare the topographical changes on the $\mathrm{C}-\mathrm{Fe}_{2} \mathrm{O}_{3}$ surface as a result of $\mathrm{AB} 113$ dye adsorption. Before adsorption (Fig. 2A), the $\mathrm{C}-$ $\mathrm{Fe}_{2} \mathrm{O}_{3}$ topography is characterized by many scattered bumps and small masses. It is clear that these masses cluster around large blocks, which may be due to the $\mathrm{Fe}_{2} \mathrm{O}_{3}$ nanoparticles attracting them. However, in Fig. 2B, it can be seen that after AB113 dye adsorption, remarkable changes occur in the surface topography of $\mathrm{C}-\mathrm{Fe}_{2} \mathrm{O}_{3}$. The previously diagnosed bumps are completely covered, and more masses are dispersed onto the $\mathrm{C}-\mathrm{Fe}_{2} \mathrm{O}_{3}$ surface, which denotes the existence of $\mathrm{AB} 113$ dye molecules on the $\mathrm{C}-\mathrm{Fe}_{2} \mathrm{O}_{3}$ surface. Similar results relevant to the AFM analysis in the present study have been presented in previous works (Broujeni et al., 2018; Kyzas et al., 2013). 


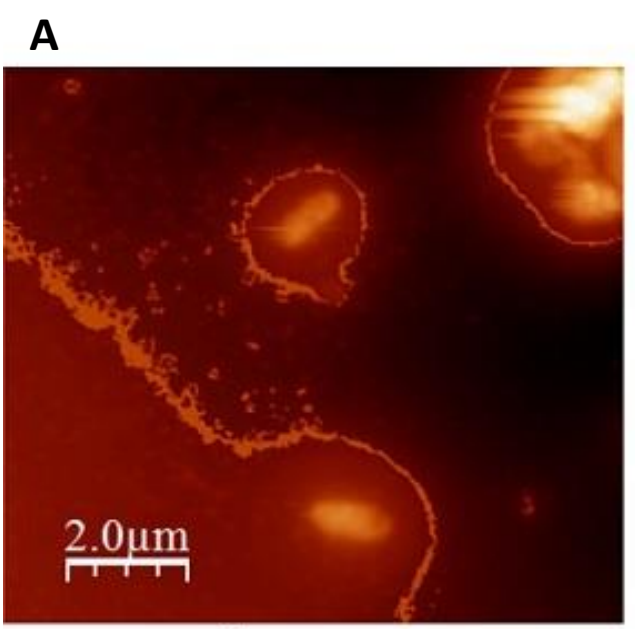

2D

B

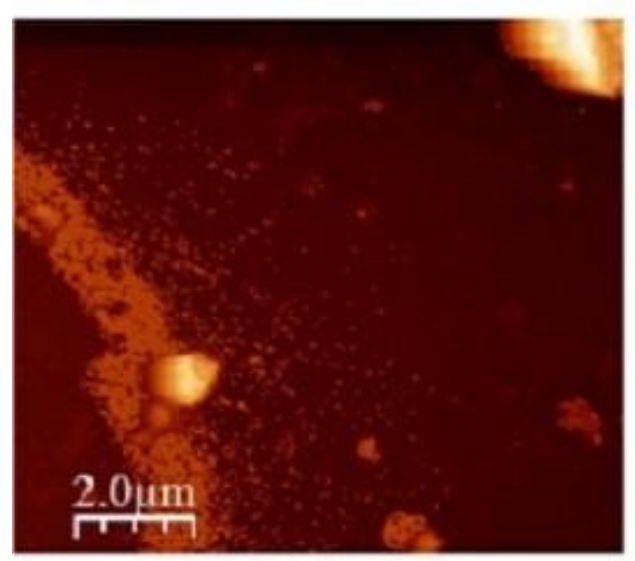

2D

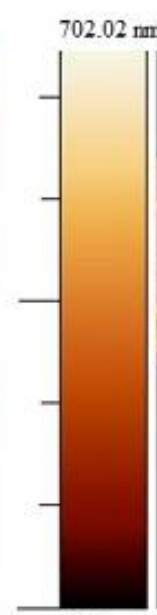

$0.00 \mathrm{~nm}$

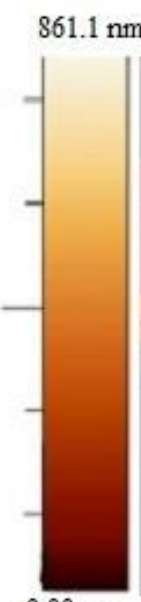

$0.00 \mathrm{~nm}$

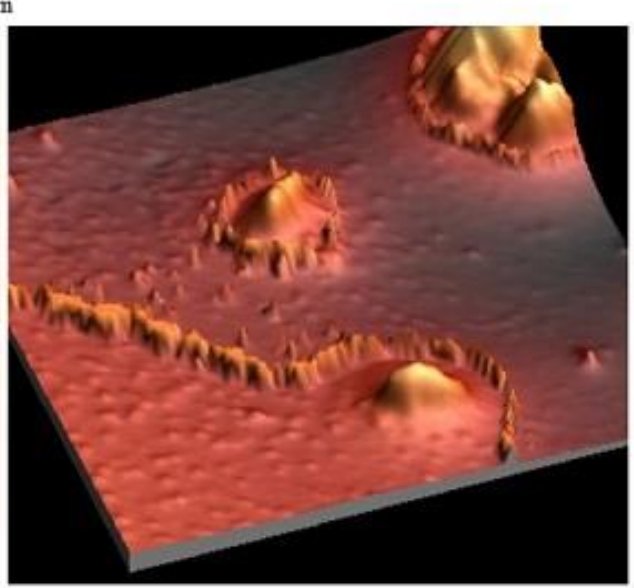

3D

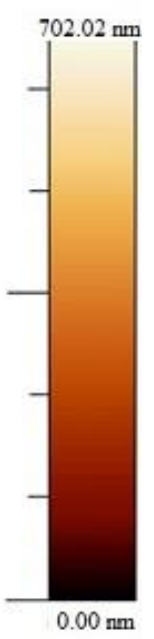

$861.1 \mathrm{~nm}$

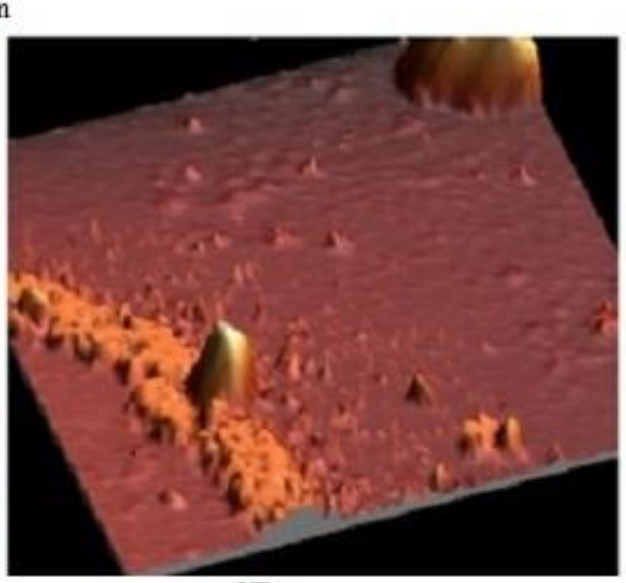

3D

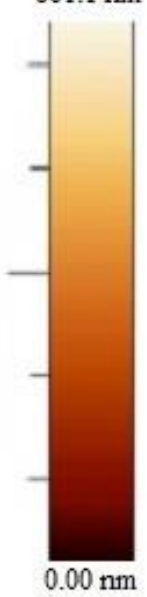

Fig. 2. 2D and 3D AFM images of $\mathrm{C}-\mathrm{Fe}_{2} \mathrm{O}_{3}$ before (A) and after (B) adsorption of $\mathrm{AB} 113$ dye.

The TGA graph of chitosan and $\mathrm{C}-\mathrm{Fe}_{2} \mathrm{O}_{3}$ is presented in Fig. 3a. The first weight loss detected up to $130{ }^{\circ} \mathrm{C}$ is related to the dehydration of water molecules from all the chitosan and $\mathrm{C}-\mathrm{Fe}_{2} \mathrm{O}_{3}$. The second thermal step occurs in the temperature range of $130-320^{\circ} \mathrm{C}$. The further dehydration, depolymerization, and acetylation process of chitosan, which often occurs at this temperature range, can be the reason for the detected weight loss. The third step is observed at temperatures $>320^{\circ} \mathrm{C}$. is the weight loss at this step is ascribed to thermal decomposition in the chitosan structure at high temperatures. These thermal steps have also been reported in other studies 
(Tabak et al., 2010; Xua et al., 2012). In the case of $\mathrm{C}-\mathrm{Fe}_{2} \mathrm{O}_{3}$, decomposition and weight loss are observed at higher temperatures compared to chitosan, which indicates an improvement in the thermal stability of chitosan by the incorporation of $\mathrm{Fe}_{2} \mathrm{O}_{3}$ nanoparticles; this has also been reported by other studies (Broujeni et al., 2018).

The FTIR spectra of chitosan $(\mathrm{C}), \mathrm{C}-\mathrm{Fe}_{2} \mathrm{O}_{3}$, and $\mathrm{C}-\mathrm{Fe}_{2} \mathrm{O}_{3}$ after reaction with $\mathrm{AB} 113$ dye $(\mathrm{C}-$ $\mathrm{Fe}_{2} \mathrm{O}_{3} / \mathrm{AB} 113$ ) samples are shown in Fig. 3b. In the chitosan spectrum, peaks related to $\mathrm{C}-\mathrm{H}, \mathrm{N}-$ $\mathrm{H}$, and $\mathrm{C}-\mathrm{O}-\mathrm{C}$ bands are observed at $2875 \mathrm{~cm}^{-1}, 1650 \mathrm{~cm}^{-1}$, and $1066 \mathrm{~cm}^{-1}$, respectively. All of the above peaks can be detected in the spectrum of $\mathrm{C}-\mathrm{Fe}_{2} \mathrm{O}_{3}$. Peaks at $1570 \mathrm{~cm}^{-1}$ and $1260 \mathrm{~cm}^{-1}$ are observed, and the peak at $2420 \mathrm{~cm}^{-1}$ in chitosan becomes the larger peak at $2340 \mathrm{~cm}^{-1}$ in C$\mathrm{Fe}_{2} \mathrm{O}_{3}$. The resulting changes in the spectrum of $\mathrm{C}-\mathrm{Fe}_{2} \mathrm{O}_{3}$ indicate the combination of $\mathrm{Fe}_{3} \mathrm{O}_{4}$ with chitosan (Broujeni et al., 2018). Additionally, the peak of the Fe-O band can be spotted at 590 $\mathrm{cm}^{-1}$, which indicates the existence of magnetite $\mathrm{Fe}_{2} \mathrm{O}_{3}$ nanoparticles in the produced samples.

The magnetization curves of chitosan and $\mathrm{C}-\mathrm{Fe}_{2} \mathrm{O}_{3}$ provided by the VSM analysis are presented in Fig. 3c and d, respectively. From this figure, the saturation magnetization value of $\mathrm{C}-\mathrm{Fe}_{2} \mathrm{O}_{3}$ is $24.5 \mathrm{emu} / \mathrm{g}$, which shows a $46 \%$ reduction in magnetization compared to $45.5 \mathrm{emu} / \mathrm{g}$ for $\mathrm{Fe}_{3} \mathrm{O}_{4}$ nanoparticles. This decrease in magnetic properties is due to the fabrication of chitosan with $\mathrm{Fe}_{3} \mathrm{O}_{4}$ magnetic nanoparticles; thus, this material can be separated from aqueous solutions using a magnet (Kyzas et al., 2013). Notably, $\mathrm{C}-\mathrm{Fe}_{2} \mathrm{O}_{3}$ is a highly magnetic material, despite containing nonmagnetic chitosan (Kavitha et al., 2012). Based on the VSM analysis, the superparamagnetic structure of the $\mathrm{Fe}_{3} \mathrm{O}_{4}$ nanoparticles is confirmed in the present study. The absence of a residual loop in the VSM diagram indicates the supermagnetic behavior of the $\mathrm{Fe}_{3} \mathrm{O}_{4}$ nanoparticles, although the interaction with chitosan leads to a decrease in their intensity (Broujeni et al., 2018). 

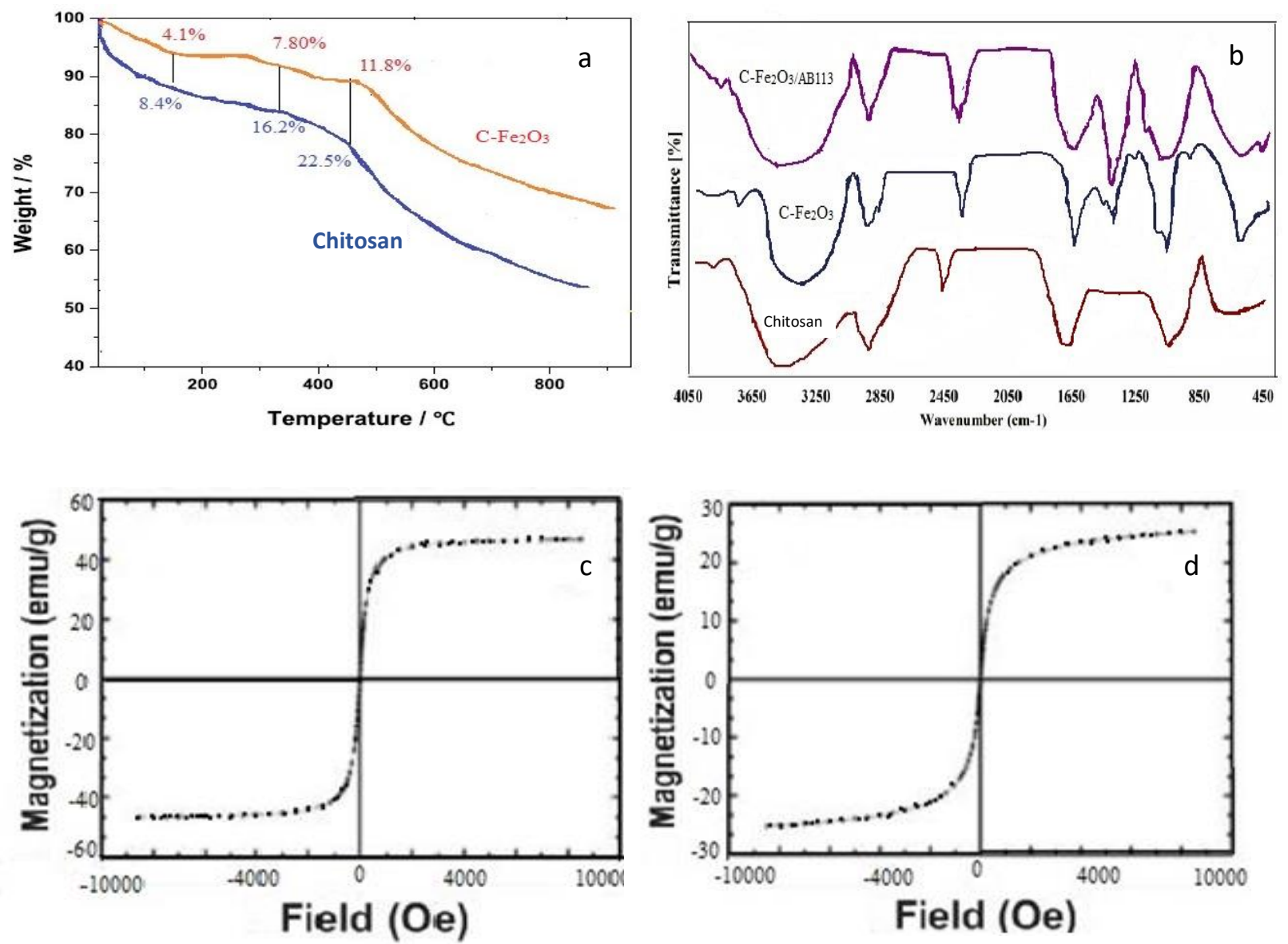

Fig. 3. TGA graph of chitosan and $\mathrm{C}-\mathrm{Fe}_{2} \mathrm{O}_{3}$ (a). FTIR spectra of chitosan, $\mathrm{C}-\mathrm{Fe}_{2} \mathrm{O}_{3}$ and $\mathrm{C}-\mathrm{Fe}_{2} \mathrm{O}_{3}$ after reaction with the $\mathrm{AB} 113$ dye $\left(\mathrm{C}-\mathrm{Fe}_{2} \mathrm{O}_{3} / \mathrm{AB} 113\right)$ (b). Magnetization curves of the $\mathrm{Fe}_{2} \mathrm{O}_{3}$ nanoparticles (c) and $\mathrm{C}-\mathrm{Fe}_{2} \mathrm{O}_{3}(\mathrm{~d})$.

\subsection{Effects of the environmental parameters on AB113 adsorption}

Several adsorption studies have demonstrated that the adsorption process of organic pollutants is significantly affected by various environmental parameters (Nasseh et al., 2021; Al-Musawi et al., 2018; Rostamian and Behnejad, 2016). Generally, the solution $\mathrm{pH}$ and temperature have a considerable effect on the adsorption process, as the ionization degree of the adsorbent surface and the dissolution rate of the organic pollutant molecules mainly depend on these two parameters. From an economic perspective and for designing large-scale adsorption treatment 
systems, the determination of the optimum adsorbent dose for the removal of pollutants is considered a key factor for such studies. Furthermore, the most important analyses in the isotherm study depend on the relationship between the equilibrium uptake of the adsorbent for the target pollutant at a constant temperature. Investigation of the effects of adsorption time at different initial pollutant concentrations is essential for kinetic studies. Additionally, Samarghandi et al. (2015) reported that the presence of some ions in aqueous solution may compete with the absorption of the target pollutant. In the present work, the effects of the abovementioned environmental parameters on AB113 dye adsorption and removal efficiency were studied, and the results are depicted in Fig. 4. Moreover, the temperature effect data are presented in the thermodynamic study.

\subsubsection{Solution pH}

The solution $\mathrm{pH}$ of the solution greatly affects the rate of adsorption; under acidic conditions, the adsorbent surface becomes protonated and has a more positive charge. This charge causes an electrostatic interaction between the adsorbent and negatively charged ions in the water. Conversely, in an alkaline state, the adsorbent surface becomes negatively charged, and the interaction between the adsorbent and the positive ions increase (Fontana et al., 2016). In the present study, the effect of solution $\mathrm{pH}$ on the removal efficiency of $\mathrm{AB} 113$ dye by $\mathrm{C}-\mathrm{Fe}_{2} \mathrm{O}_{3}$ was investigated from pH 3 to 11, and the results are depicted in Fig. 4a (AB113 concentration: 10 $\mathrm{mg} / \mathrm{L}$, adsorption time: $120 \mathrm{~min}$, and $\mathrm{C}-\mathrm{Fe}_{2} \mathrm{O}_{3}$ dose: $\left.0.6 \mathrm{~g} / \mathrm{L}\right)$. As seen, with an increasing $\mathrm{pH}$, the dye adsorption efficiency decreases significantly. At low $\mathrm{pH}$ values, more protons exist, so the amine groups in chitosan are protonated; thus, the electrostatic force between the negatively charged dye molecules and the positively charged adsorbent sites increases and more adsorption occurs (Tabak et al., 2010). Additionally, the high adsorption under acidic conditions can be explained by a $\mathrm{pH}_{\mathrm{pzc}}$ analysis. In the present study, the $\mathrm{pH}_{\mathrm{pzc}}$ of $\mathrm{C}-\mathrm{Fe}_{2} \mathrm{O}_{3}$ is determined to be 
approximately 7 (inset picture in Fig. 4a). Based on this, at solution $\mathrm{pH}$ values greater than 7 , the surface of $\mathrm{C}-\mathrm{Fe}_{2} \mathrm{O}_{3}$ is negatively charged, while for $\mathrm{pH}$ values lower than 7 , the surface has a positive charge (Hilal et al., 2012). In contrast, the AB113 dye molecule (having two sulfonated $\left(-\mathrm{SO}_{3}{ }^{-}\right)$groups) is a disulfonate acid dye (with a $\mathrm{pKa}$ of 0.5$)$, and at $\mathrm{pH}$ values higher than 0.5 , AB113 tends to have a negative charge. Thus, under acidic conditions, increasing the density of positive charges on the $\mathrm{C}-\mathrm{Fe}_{2} \mathrm{O}_{3}$ surface may be behind the enhanced $\mathrm{AB} 113$ removal. At higher $\mathrm{pH}$ values, $\mathrm{OH}^{-}$in the environment competes with the studied pollutant for combining with chitosan, thus reducing the adsorption rate of $\mathrm{AB} 113$ dye on the cationic adsorbent (Bazrafshan et al., 2013).

\subsection{2 $\mathrm{C}-\mathrm{Fe}_{2} \mathrm{O}_{3}$ dose}

The effect of the $\mathrm{C}-\mathrm{Fe}_{2} \mathrm{O}_{3}$ dose was investigated by varying the dose from $0.1 \mathrm{~g} / \mathrm{L}$ to $1 \mathrm{~g} / \mathrm{L}$ with the following experimental conditions: initial concentration of $\mathrm{AB} 113=10 \mathrm{mg} / \mathrm{L}, \mathrm{pH}=3$, and adsorption time: 120 min. As shown in Fig. 8, it is revealed that with an increasing quantity of $\mathrm{C}-\mathrm{Fe}_{2} \mathrm{O}_{3}$, the removal efficiency also increases. This result is because of the increase in total surface area by increasing the $\mathrm{C}-\mathrm{Fe}_{2} \mathrm{O}_{3}$ dose, which in turn increases the availability of active adsorption sites for AB113 adsorption. The maximum adsorption of AB113 is observed at 0.6 $\mathrm{g} / \mathrm{L}$ with an adsorption capacity of $124.2 \mathrm{mg} / \mathrm{g}$ for $\mathrm{C}-\mathrm{Fe}_{2} \mathrm{O}_{3}$. Therefore, a dose of $0.6 \mathrm{~g} / \mathrm{L}$ was selected for further batch experiments. Notably, the removal of $\mathrm{AB} 113$ onto $\mathrm{C}-\mathrm{Fe}_{2} \mathrm{O}_{3}$ is found to be constant with an increasing dose. The reduction in AB113 removal with a further increase in the adsorbent dose might be due to a decrease in the available sites and surface area and due to the agglomeration of $\mathrm{C}-\mathrm{Fe}_{2} \mathrm{O}_{3}$ particles that occurs at high doses (Dotto et al., 2011). The results of this experiment are in accordance with the results of previous studies (Yao et al., 2010).

\subsubsection{AB113 concentration and contact time}


Fig. $4 \mathrm{c}$ shows the kinetics curves, which represent the removal efficiency of AB113 dye as a function of adsorption time (0-300 min) with different concentrations $(10-100 \mathrm{mg} / \mathrm{L})$. The other parameters were fixed as the following: $\mathrm{pH}=3$ and $\mathrm{C}-\mathrm{Fe}_{2} \mathrm{O}_{3}$ dose $=0.6 \mathrm{~g} / \mathrm{L}$. The plotted curves of Fig. $4 c$ present similar profiles at all analyzed concentrations of AB113 dye. These curves show a very steep increase in the first $60 \mathrm{~min}$ of adsorption, and after $90 \mathrm{~min}$ of adsorption, the slopes of these curves gradually level off until reaching equilibrium at 120 min. Clearly, the AB113 removal efficiency increases from $77.93 \%$ to $99.68 \%$ when the $\mathrm{AB} 113$ dye concentration is decreased from $100 \mathrm{mg} / \mathrm{L}$ to $10 \mathrm{mg} / \mathrm{L}$. The decrease in the removal efficiency with an increasing initial $\mathrm{AB} 113$ concentration is because of the increase in the competition rate among AB113 molecules to occupy the available active sites of a fixed quantity of $\mathrm{C}-\mathrm{Fe}_{2} \mathrm{O}_{3}$. In addition, the increase in the $\mathrm{AB} 113$ dye concentration can lead to the rapid exhaustion of the used adsorbent; therefore, the adsorbent can become saturated (Joshi et al., 2019). On the other hand, Fig. 4c reveals that the $\mathrm{AB} 113$ removal efficiency is faster in the first $30 \mathrm{~min}$, and the removal efficiency beyond $30 \mathrm{~min}$ is slightly slower. This result is because in the first $30 \mathrm{~min}$ of adsorption, the active adsorption sites on $\mathrm{C}-\mathrm{Fe}_{2} \mathrm{O}_{3}$ are easily available for $\mathrm{AB} 113$ molecules (Madrakian et al., 2011). Afterward, the number of free sites decrease; hence, the AB113 dye removal efficiency is slightly slower, particularly after $60 \mathrm{~min}$ of adsorption.

\subsubsection{Interference ions}

Several studies have shown that different ions can interfere with the adsorption process by affecting the electrostatic interactions between the adsorbent and pollutant molecules (Balarak et al., 2016; Samarghandi et al., 2015). In fact, the reason for this phenomenon is that these ions have a higher ability to adsorb or neutralize the positive or negative charges on the adsorbent surface; thus, they inhibit the attraction between the pollutant molecules and adsorbent particles 
(Balarak et al., 2016). In the present study, the competition of $\mathrm{NaCl}, \mathrm{NaNO}_{3}, \mathrm{Na}_{2} \mathrm{CO}_{3}$, and $\mathrm{MgSO}_{4}$ ions on $\mathrm{AB} 113$ dye adsorption was investigated and compared with a control sample. This experiment was performed under the optimized conditions found from the previous analyses $\left(\mathrm{pH}=3, \mathrm{AB} 113\right.$ concentration $=10 \mathrm{mg} / \mathrm{L}, \mathrm{C}-\mathrm{Fe}_{2} \mathrm{O}_{3}$ dose $=0.6 \mathrm{~g} / \mathrm{L}$, and adsorption time $=120$ min), and the results are presented in Fig. 4d. In addition, the initial concentration of these interference ions was fixed at $10 \mathrm{mg} / \mathrm{L}$. The presence of $\mathrm{NaCl}$ has the greatest impact on the AB113 removal efficiency. From this experiment, the effect of the presence of interference ions on the $\mathrm{AB} 113$ removal efficiency can be ranked as $\mathrm{NaCl}>\mathrm{NaNO}_{3}>\mathrm{MgSO}_{4}>\mathrm{Na}_{2} \mathrm{CO}_{3}$. 

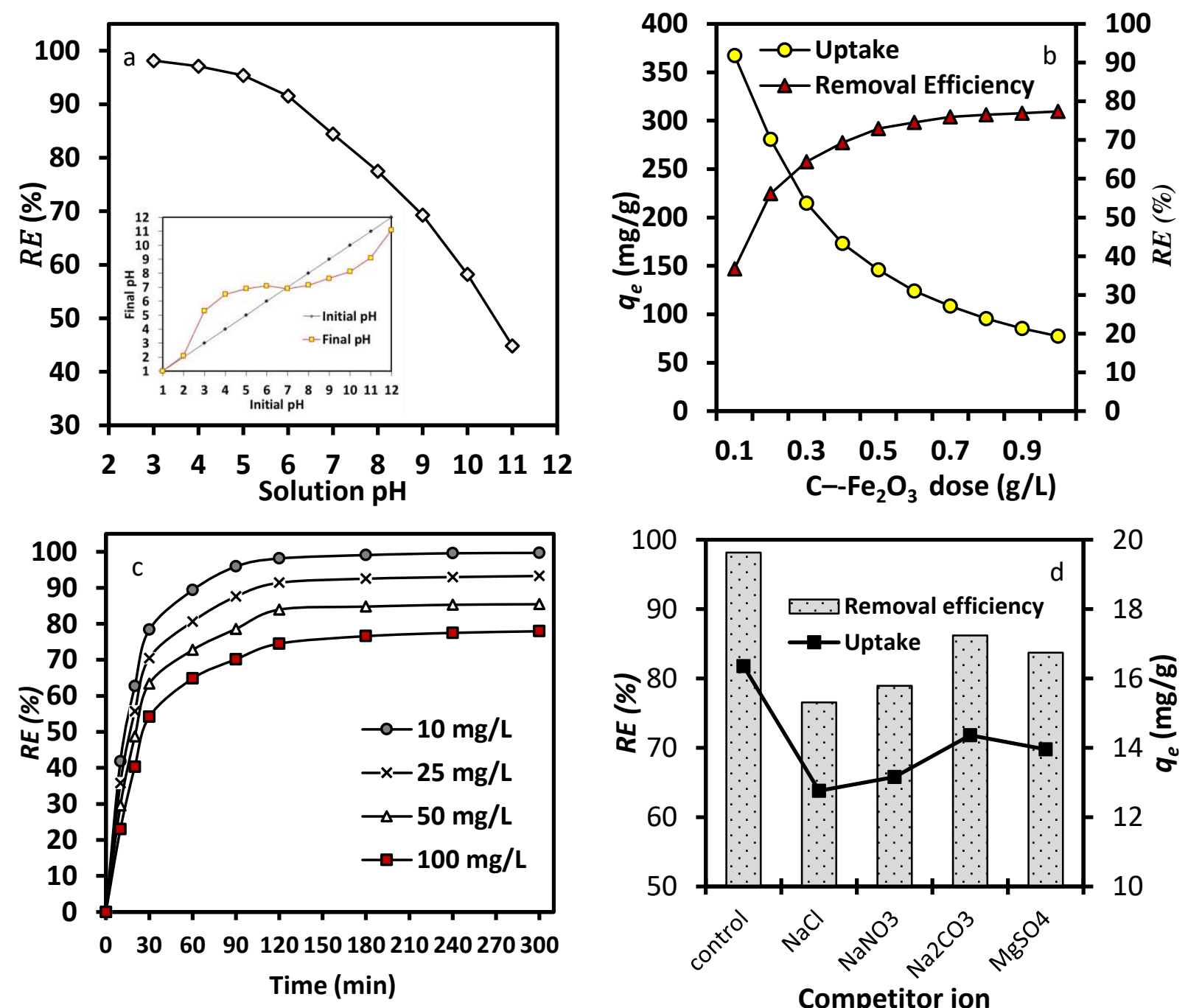

Competitor ion

Fig. 4. Effect study of $\mathrm{pH}$ and the $\mathrm{pH}_{\mathrm{pzc}}$ analysis (a), $\mathrm{C}-\mathrm{Fe}_{2} \mathrm{O}_{3}$ dose (b), Initial $\mathrm{Ab} 113$ dye concentration (c), and Interference ions (d).

\subsection{Kinetics study}

Analyses of the kinetic reaction are essential to evaluate the applicability of the used adsorbent, as it is useful for understanding the rate and type of adsorption (chemisorption, physisorption, or mixed). In addition, the determination of a kinetic model that can describe the experimental data of the kinetic reaction of an adsorbent-adsorbate system is necessary for the precise design of large-scale adsorption treatments (Al-Musawi et al., 2018; Balarak et al., 2016). Therefore, the 
experimental data shown in Fig. 4c are first treated using Equation 2 and then modeled with the pseudo-first-order (PFO) (Equation 8) and pseudo-second-order (PSO) (Equation 9) kinetic models (Ferrero et al., 2018; Somasekhara et al., 2016).

$q_{t}=q_{e}\left(1-\exp \left(-k_{1} t\right)\right)$

$q_{t}=\frac{q_{e}^{2} k_{2} t}{1+q_{e} k_{2} t}$

where $K_{1}(1 / \mathrm{min})$ and $K_{2}(\mathrm{~g} / \mathrm{mg} \cdot \mathrm{min})$ are the PFO and PSO rate constants, respectively.

Nonlinear regression methodology using the MATLAB program was applied to model the kinetic data. Table 1 lists the results of the kinetic models and regression level parameters of AB113 dye adsorption onto $\mathrm{C}--\mathrm{Fe}_{2} \mathrm{O}_{3}$. Note that the fitting of each kinetic model with the experimental data is estimated in accordance with the $R^{2}, S S E, R M S E, x^{2}$, and $A R E$ values as well as the convergence between the calculated uptake $\left(q_{e}(\mathrm{cal})\right)$ and experimental uptake $\left(q_{e}(\exp )\right)$. The results show that high regression levels are obtained for the fitting of the PSO model compared to those for the fitting of the PFO model (Table 1). In addition, the values of $q_{e}(\mathrm{cal})$ determined from the application of the PSO model are close to the $q_{e}(\exp )$ values. Therefore, the adsorption kinetics of the $\mathrm{AB} 113$ dye on $\mathrm{C}--\mathrm{Fe}_{2} \mathrm{O}_{3}$ follows PSO kinetics, suggesting a chemisorption process (Mohammed et al., 2019; Khodadadi et al., 2019).

By plotting the kinetics data according to the intraparticle diffusion model (IPD, Equation 12), it is found that the kinetics adsorption of $\mathrm{AB} 113$ dye onto $\mathrm{C}-\mathrm{Fe}_{2} \mathrm{O}_{3}$ consists of three consecutive phases, as shown in Fig. 5: bulk diffusion, film diffusion, and pore diffusion. In fact, the first phase observed at $3<t^{0.5}<5.5 \min ^{0.5}$ represents the surface and IPD processes, the second phase observed at $5.5<t^{0.5}<11 \min ^{0.5}$ represents liquid film diffusion, and the third phase observed at $11<t^{0.5}<17.5 \min ^{0.5}$ represents the diffusion of $\mathrm{AB} 113$ dye molecules through 
pores to the active sites of $\mathrm{C}-\mathrm{Fe}_{2} \mathrm{O}_{3}$; then, equilibrium conditions are achieved. In the present study, the first phase is modeled as a term in the IPD model. This is an important step in adsorption studies, as the IPD model provides information about the role of the IPD rate in controlling adsorption (Balarak et al., 2016).

$q_{t}=K_{b} t^{0.5}+C$

where $K_{b}\left(\mathrm{mg} / \mathrm{g} \cdot \mathrm{min}^{0.5}\right)$ is the rate constant of the IPD model and $C(\mathrm{mg} / \mathrm{g})$ is the IPD constant that provides information about the thickness of the boundary layer.

The values of $K_{b}$ and $C$ represent the slope and intercept of the linear plot equation of the first phase in Fig. 5, respectively. The results show a high compatibility level $\left(\mathrm{R}^{2}>0.99\right)$ of the AB113 kinetic data with the IPD model (Table 1). Therefore, it can be concluded that compared to other diffusion types, the IPD process is the dominant rate-controlling step during the adsorption of AB113 dye onto $\mathrm{C}-\mathrm{Fe}_{2} \mathrm{O}_{3}$. This result is because the linear plot of $q_{t}$ versus $t^{1 / 2}$ does not pass through the origin; therefore, boundary layer diffusion occurs during the adsorption process. The positive values of $\mathrm{C}$ for all $\mathrm{AB} 113$ concentrations are indicative of involving the IPD in the adsorption process; nevertheless, the adsorption process is governed not only by IDP as the ratelimiting step but also by other factors controlling AB113 adsorption on $\mathrm{C}-\mathrm{Fe}_{2} \mathrm{O}_{3}$. 
Table 1. Results of the kinetic analyses of $\mathrm{AB} 113$ dye adsorption on $\mathrm{C}-\mathrm{Fe}_{2} \mathrm{O}_{3}$

\begin{tabular}{|c|c|c|c|c|c|c|c|c|}
\hline \multirow[b]{2}{*}{$C_{0}(\mathrm{mg} / \mathrm{L})$} & \multirow[b]{2}{*}{$q_{e}(\exp )$} & \multicolumn{7}{|c|}{ PFO kinetics model } \\
\hline & & $q_{e}(\mathrm{cal})$ & $K_{1}$ & $R^{2}$ & $x^{2}$ & $R M S E$ & $S S E$ & $A R E$ \\
\hline 10 & 16.61 & 9.24 & 0.026 & 0.977 & 11.20 & 17.10 & 9.25 & 13.84 \\
\hline 25 & 38.86 & 21.18 & 0.023 & 0.975 & 13.95 & 11.84 & 9.38 & 13.02 \\
\hline 50 & 71.21 & 42.84 & 0.022 & 0.969 & 14.48 & 11.95 & 18.41 & 9.28 \\
\hline \multirow[t]{2}{*}{100} & 129.80 & 11.71 & 0.021 & 0.978 & 8.46 & 6.45 & 4.71 & 8.73 \\
\hline & & \multicolumn{7}{|c|}{ PSO kinetics model } \\
\hline$C_{0}(\mathrm{mg} / \mathrm{L})$ & $q_{e}(\exp )$ & $q_{e}(c a l)$ & $K_{2}$ & $R^{2}$ & $x^{2}$ & $R M S E$ & $S S E$ & $A R E$ \\
\hline 10 & 16.61 & 17.36 & 0.0053 & 0.999 & 1.48 & 2.15 & 1.09 & 2.71 \\
\hline 25 & 38.86 & 40.98 & 0.0018 & 0.999 & 1.76 & 2.95 & 1.49 & 3.11 \\
\hline 50 & 71.21 & 75.75 & 0.0008 & 0.998 & 2.35 & 1.79 & 4.18 & 1.48 \\
\hline \multirow[t]{2}{*}{100} & 129.80 & 140.84 & 0.0003 & 0.998 & 3.78 & 4.29 & 2.18 & 1.73 \\
\hline & & \multicolumn{7}{|c|}{ Intraparticle diffusion model } \\
\hline$C_{0}(\mathrm{mg} / \mathrm{L})$ & & $K_{b}\left(\mathrm{mg} / \mathrm{g} \cdot \min ^{0.5}\right)$ & $C(m g / g)$ & $R^{2}$ & & & & \\
\hline 10 & & 2.63 & 1.35 & 0.999 & & & & \\
\hline 25 & & 6.25 & 4.85 & 0.999 & & & & \\
\hline 50 & & 12.1 & 13.9 & 0.998 & & & & \\
\hline 100 & & 13.4 & 32.9 & 0.999 & & & & \\
\hline
\end{tabular}

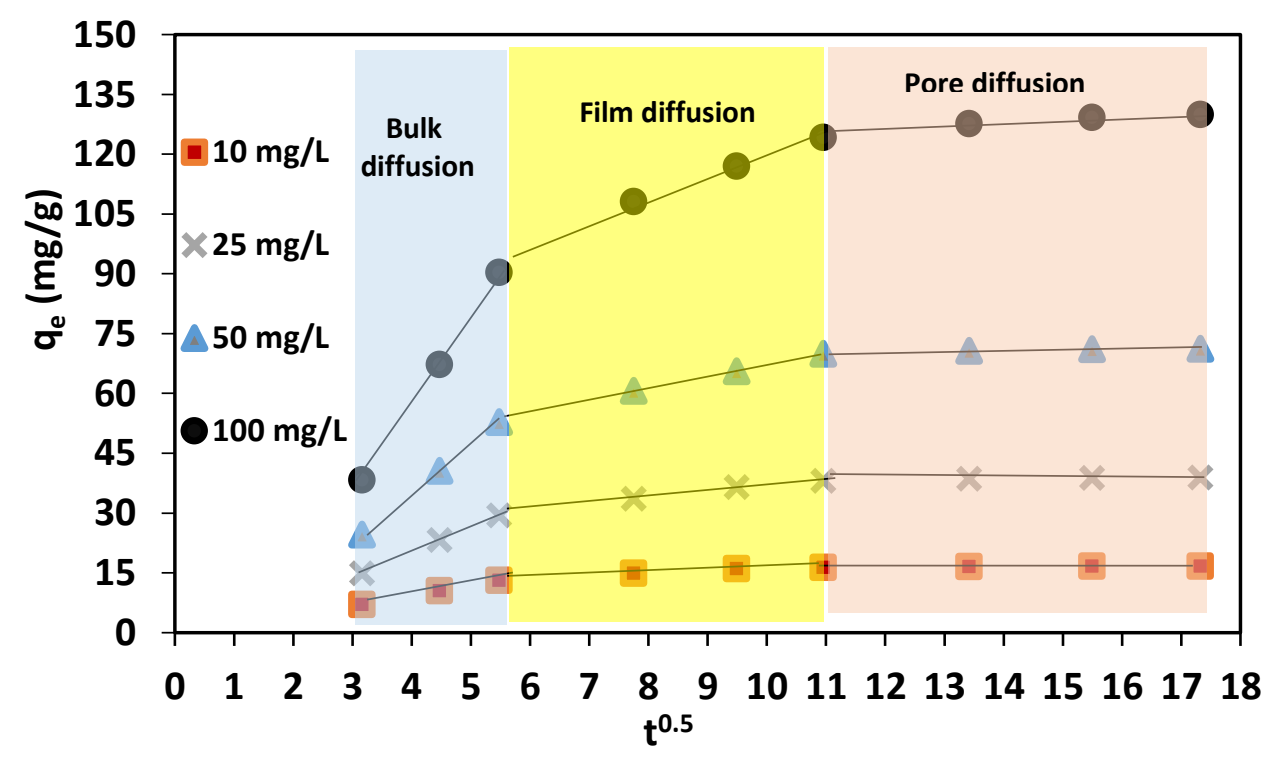

Fig. 5. Three stages of the kinetics adsorption of AB113 onto $\mathrm{C}-\mathrm{Fe}_{2} \mathrm{O}_{3}$. 


\subsection{Adsorption isotherms}

To clarify the interaction between the adsorbent and target pollutant, adsorption isotherms, i.e., the Langmuir (Equation 13), Freundlich (Equation 14), Dubinin-Radushkevich (D-R, Equation 15), and Temkin (Equation 16) equations, were employed. The occurrence of adsorption in monolayers at homogeneous sites on the adsorbent is hypothesized by the Langmuir model. In contrast, the Freundlich isotherm describes adsorption on a heterogeneous surface and reversible adsorption (Akar et al., 2010). Moreover, by the D-R model, the chemical or physical mechanism is appraised (Arami et al., 2006). Through employment of the Temkin isotherm, the heat of adsorption and the adsorbent-adsorbate interaction are defined (Fiorentin et al., 2010; Lakshmi et al., 2009).

$q_{e}=\frac{Q_{m} K_{L} C_{e}}{1+K_{L} C_{e}}$

$q_{e}=K_{F} C_{e}^{1 / n}$

$q_{e}=q_{m} \exp \left(-\beta \varepsilon^{2}\right)$

$q_{e}=B \ln \left(K_{T} C_{e}\right)$

where $Q_{m}(\mathrm{mg} / \mathrm{g})$ is a very important adsorption parameter in the Langmuir model, denoting the maximum $q_{t}$ of the used adsorbent for the target pollutant; $K_{L}(\mathrm{~L} / \mathrm{mg})$ is an equilibrium constant reflecting the affinity level of the active sites of the adsorbent; $K_{F}$ is the Freundlich constant, indicative of the binding energy $(\mathrm{mg} / \mathrm{g})(\mathrm{L} / \mathrm{mg})^{1 / \mathrm{n}} ; \frac{1}{n}$ is the heterogeneity parameter; $q_{m}$ is the theoretical adsorption capacity $(\mathrm{mg} / \mathrm{g})$ of the D-R model; $\beta\left(\mathrm{mol}^{2} / \mathrm{kJ}^{2}\right)$ is the activity coefficient constant associated with the mean free sorption energy, which is denoted by $E=\frac{1}{\sqrt{-2 \beta}}(\mathrm{kJ} / \mathrm{mol})$; $\varepsilon=R T \ln \left(1+\frac{1}{C_{e}}\right)$ is the Polanyi potential $(\mathrm{kJ} / \mathrm{mol}) ; K_{T}$ and $B=\frac{R T}{b}$ are Temkin model constants 
that provide information about the heat of sorption $(\mathrm{J} / \mathrm{mol}) ; b$ is the Temkin isotherm constant $(\mathrm{L} / \mathrm{g}) ; R$ is the ideal gas constant $(8.314 \mathrm{~J} /(\mathrm{mol} . \mathrm{K}))$; and $T$ is the thermodynamic absolute temperature $(\mathrm{K})$.

In addition to the Langmuir model (Equation 13), the characteristics of adsorption can be defined based on the dimensionless separation factor $\left(R_{L}\right)$ (Equation 17). Based on the value of this factor, the favorable adsorption case can only be detected in the case of $0<R_{L}<1$.

$R_{L}=\frac{1}{\left(1+K_{L} C_{0}\right)}$

Table 2 lists the determined values of the isotherm model parameters. The results show that the fitting parameters are high for the Freundlich model compared to those for the other isotherm models; thus, the isothermal data of $\mathrm{AB} 113$ dye adsorption on $\mathrm{C}-\mathrm{Fe}_{2} \mathrm{O}_{3}$ is consistent with the Freundlich model. This finding indicates that the AB113 dye molecules demonstrate multilayer adsorption at the heterogeneous adsorption sites of $\mathrm{C}-\mathrm{Fe}_{2} \mathrm{O}_{3}$. In addition, as the value of the Freundlich parameter $n$ is herein considered greater than one, the AB113 dye on the $\mathrm{C}-\mathrm{Fe}_{2} \mathrm{O}_{3}$ adsorption process is suitable (Akar et al., 2009). The maximum adsorption capacity of AB113 by $\mathrm{C}-\mathrm{Fe}_{2} \mathrm{O}_{3}$ based on the fitting results of the Langmuir model is $128.2 \mathrm{mg} / \mathrm{g}$. Furthermore, the value of the $R_{L}$ parameter of the Langmuir model is between zero and one, indicating the favorable adsorption process of $\mathrm{AB} 113$ dye on $\mathrm{C}-\mathrm{Fe}_{2} \mathrm{O}_{3}$ (Zazouli et al., 2013). Since the $E$ obtained from the $\mathrm{D}-\mathrm{R}$ isotherm is less than $8 \mathrm{~kJ} / \mathrm{mol}$, the adsorption of $\mathrm{AB} 113$ on $\mathrm{C}-\mathrm{Fe}_{2} \mathrm{O}_{3}$ is physical in nature (50). The theoretical models used for fitting the experimental isothermal data of $\mathrm{AB} 113$ dye adsorption on $\mathrm{C}-\mathrm{Fe}_{2} \mathrm{O}_{3}$ are graphically presented in Fig. 6.

Considering the results of the isotherm study, the adsorption capacity of $\mathrm{C}-\mathrm{Fe}_{2} \mathrm{O}_{3}$ was compared with that of other adsorbents in dye removal. As reported in Table 3, the adsorption capacity of 
$\mathrm{C}-\mathrm{Fe}_{2} \mathrm{O}_{3}$ is good and shows high adsorption compared to other adsorbents. Therefore, $\mathrm{C}-\mathrm{Fe}_{2} \mathrm{O}_{3}$ is more effective than other adsorbents for dye removal.

Table 2. Isotherm model parameters of $\mathrm{AB} 113$ dye adsorption on $\mathrm{C}-\mathrm{Fe}_{2} \mathrm{O}_{3}$ (conditions of this experiment were fixed at the following optimized values: $\mathrm{pH}=3$; $\mathrm{C}-\mathrm{Fe}_{2} \mathrm{O}_{3}$ dose $=0.1-1 \mathrm{~g} / \mathrm{L}$;

$\mathrm{AB} 113$ dye concentration $=10 \mathrm{mg} / \mathrm{L} ;$ adsorption time $=120 \mathrm{~min}$, and temperature $=25 \pm 2{ }^{\circ} \mathrm{C}$ )

\begin{tabular}{|c|c|c|c|c|c|c|c|}
\hline \multicolumn{2}{|l|}{ Freundlich } & \multicolumn{2}{|l|}{ Langmuir } & \multicolumn{2}{|c|}{ Dubinin-Radushkevich } & \multicolumn{2}{|l|}{ Temkin } \\
\hline$K_{F}(\mathrm{mg} / \mathrm{g})(\mathrm{L} / \mathrm{mg})^{1 / \mathrm{n}}$ & 6.961 & $Q_{m}(\mathrm{mg} / \mathrm{g})$ & 128.200 & $q_{m}(\mathrm{mg} / \mathrm{g})$ & 58.710 & $B(\mathrm{~J} / \mathrm{mol})$ & 47.401 \\
\hline $1 / n$ & 0.392 & $R_{L}$ & 0.209 & $\beta\left(\mathrm{mol}^{2} / \mathrm{kJ}^{2}\right)$ & 0.008 & $K_{T}(\mathrm{~J} / \mathrm{mol})$ & 19.411 \\
\hline$n$ & 2.551 & $K_{L}(\mathrm{~L} / \mathrm{mg})$ & 0.322 & $E(\mathrm{~kJ} / \mathrm{mol})$ & 7.491 & $b(\mathrm{~L} / \mathrm{g})$ & 52.260 \\
\hline$R^{2}$ & 0.994 & $R^{2}$ & 0.941 & $R^{2}$ & 0.674 & $R^{2}$ & 0.839 \\
\hline$x^{2}$ & 2.920 & $x^{2}$ & 4.714 & $x^{2}$ & 11.650 & $x^{2}$ & 4.762 \\
\hline$R M S E$ & 2.490 & $R M S E$ & 3.961 & $R M S E$ & 4.792 & $R M S E$ & 9.890 \\
\hline$S S E$ & 1.843 & $S S E$ & 6.721 & $S S E$ & 9.460 & $S S E$ & 14.811 \\
\hline$A R E$ & 2.080 & $A R E$ & 4.340 & $A R E$ & 10.380 & $A R E$ & 19.371 \\
\hline
\end{tabular}

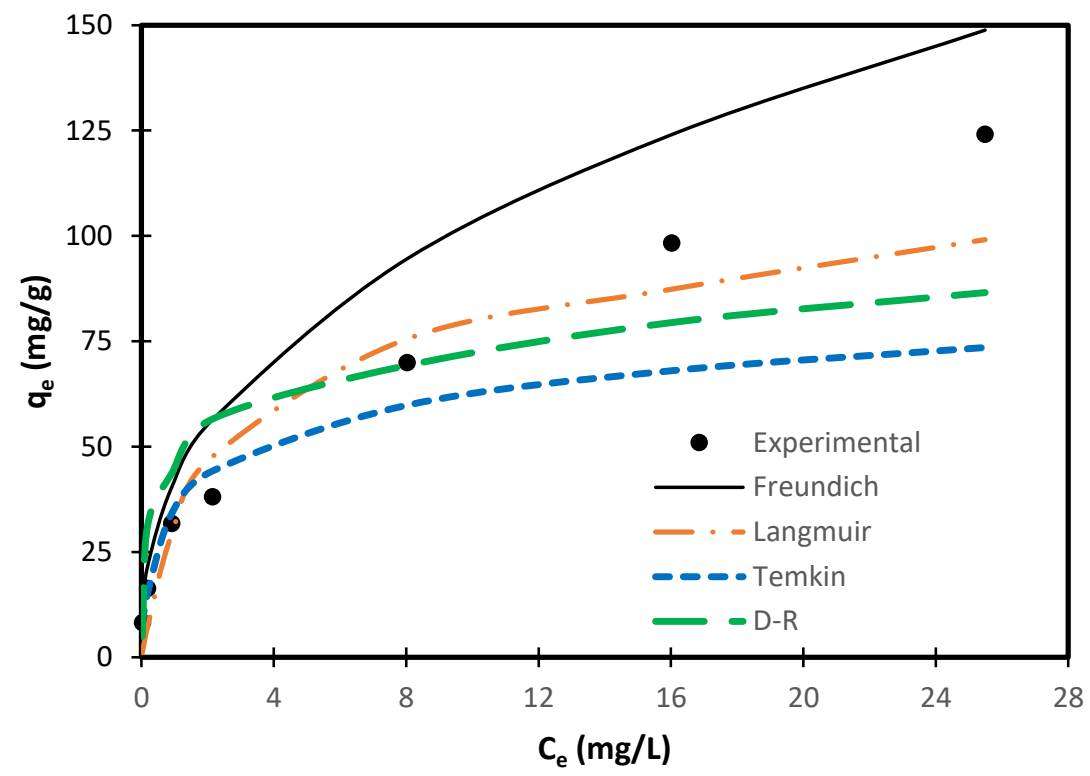

Fig. 6. Experimental and theoretical isothermal data of $\mathrm{AB} 113$ dye adsorption on $\mathrm{C}-\mathrm{Fe}_{2} \mathrm{O}_{3}$. 
Table 3. Comparison between the maximum Langmuir adsorption capacities $\left(Q_{m}\right)$ of $\mathrm{C}-\mathrm{Fe}_{2} \mathrm{O}_{3}$ and of other adsorbents used for dyes removal

\begin{tabular}{llll}
\hline Adsorbents & Anionic dye & $\boldsymbol{Q}_{\boldsymbol{m}}(\mathbf{m g} / \mathbf{g})$ & Reference \\
\hline Multi-walled carbon nanotubes & Acid Blue 225 & 10.2 & (Balarak et al., 2016) \\
Cyperus rotundus & Acid Orang 7 & 31.98 & (Balarak et al., 2016) \\
Azolla filiculoides & Acid Blue 92 & 36.98 & (Balarak et al., 2016) \\
Orange bagasse & Reactive Blue 5 & 40.71 & (Fiorentin et al., 2010) \\
Hazelnut shell & Acid Blue 25 & 60.2 & (Ferrero et al., 2007) \\
Jujuba seed & Congo Red & 55.56 & (Somasekhara et al., 2012) \\
Canola & Acid Blue 113 & 56.9 & (Zazouli et al., 2013) \\
Durian peel & Acid Green 25 & 63.29 & (Hameed et al., 2008) \\
Rice husk & Acid Red 66 & 65.1 & (Balarak et al., 2018) \\
Risk husk & Acid Blue 74 & 97.06 & (Lakshmi et al., 2009) \\
Pyracantha coccinea & Acid Red 44 & 105.1 & (Akar et al., 2010) \\
Thuja orientalis cone & Acid Blue 40 & 114.9 & (Akar et al., 2008) \\
Meal hull & Acid Blue 92 & 114.9 & (Arami et al., 2010) \\
C-Fe $\mathrm{O}_{3}$ & Acid Blue 113 & 128.2 & This study \\
\hline & & & \\
\hline & & &
\end{tabular}

\subsection{Effect of temperature and the thermodynamic study}

The effect of temperature on the AB113 dye removal efficiency was examined in the range of $288-318 \mathrm{~K}$ as a function of adsorption time (0-300), and the results are depicted in Fig. 7. This figure clarifies the positive effect of an increasing temperature on the removal efficiency of AB113 dye on $\mathrm{C}-\mathrm{Fe}_{2} \mathrm{O}_{3}$. This behavior of improved removal efficiency with an increasing 
temperature is due to in the enhanced diffusion rate or kinetic energy of AB113 dye molecules across the bulk and internal boundary layers of the $\mathrm{C}-\mathrm{Fe}_{2} \mathrm{O}_{3}$ particle (Mohammed et al., 2019).

The thermodynamic parameters, including the enthalpy $\left(\Delta H^{o}\right)(\mathrm{kJ} / \mathrm{mol})$, entropy $\left(\Delta S^{o}\right)$ $(\mathrm{kJ} / \mathrm{mol} \cdot \mathrm{K})$, and Gibbs free energy $\left(\Delta G^{o}\right)(\mathrm{kJ} / \mathrm{mol})$, were calculated after determining the $q_{e}$ values of the data in Fig. 7 using Equation 2. The above three parameters were determined using Equations 18-20 (Meziti et al., 2012; Hameed et al., 2008). From these equations, $\Delta H^{o}$ and $\Delta S^{o}$ can be directly calculated from the linear plot of $\ln K_{o}$ vs. $1 / T$, where $K_{o}(\mathrm{~L} / \mathrm{mg})$ is the equilibrium constant $\left(=\frac{q_{e}}{C_{e}}\right)$. The slope and intercept with the y-axis of the obtained trend line equation represent $\left(-\Delta H^{o} / R\right)$ and $\left(\Delta S^{o} / R\right)$, respectively. Thereafter, $\Delta G^{o}$ can be calculated using Equation 20.

$\Delta G^{o}=-R T\left(\ln K_{o}\right)$

$\ln K_{o}=\frac{\Delta S^{o}}{R}-\frac{\Delta H^{o}}{R T}$

$\Delta G^{o}=\Delta H^{o}-T \Delta S^{o}$,

Table 4 presents the results of the thermodynamic analysis. A positive $\Delta S^{o}$ indicates the high randomness of $\mathrm{AB} 113$ dye adsorption and approves the stability of the adsorption process. The negative values of $\Delta G^{o}$ suggest that the adsorption of $\mathrm{AB} 113$ dye on $\mathrm{C}-\mathrm{Fe}_{2} \mathrm{O}_{3}$ is a spontaneous reaction (Chu et al., 2013; Han et al., 2009). Moreover, the increase in the negative values of $\Delta G^{o}$ with an increase in temperature may be because of the dehydration phenomena of both adsorbent particles and pollutant molecules at high temperatures, which simplifies the reaction between them and ultimately makes the adsorption of $\mathrm{AB} 113$ dye on $\mathrm{C}-\mathrm{Fe}_{2} \mathrm{O}_{3}$ more favorable at high temperatures (Gok et al., 2010). Furthermore, a positive $\Delta H^{o}$ refers to the endothermic adsorption process of the $\mathrm{AB} 113$ dye on $\mathrm{C}-\mathrm{Fe}_{2} \mathrm{O}_{3}$, which means the formation of strong 
chemical bonds between the adsorbed AB113 molecules and the $\mathrm{C}-\mathrm{Fe}_{2} \mathrm{O}_{3}$ surface (Suna et al., 2010).

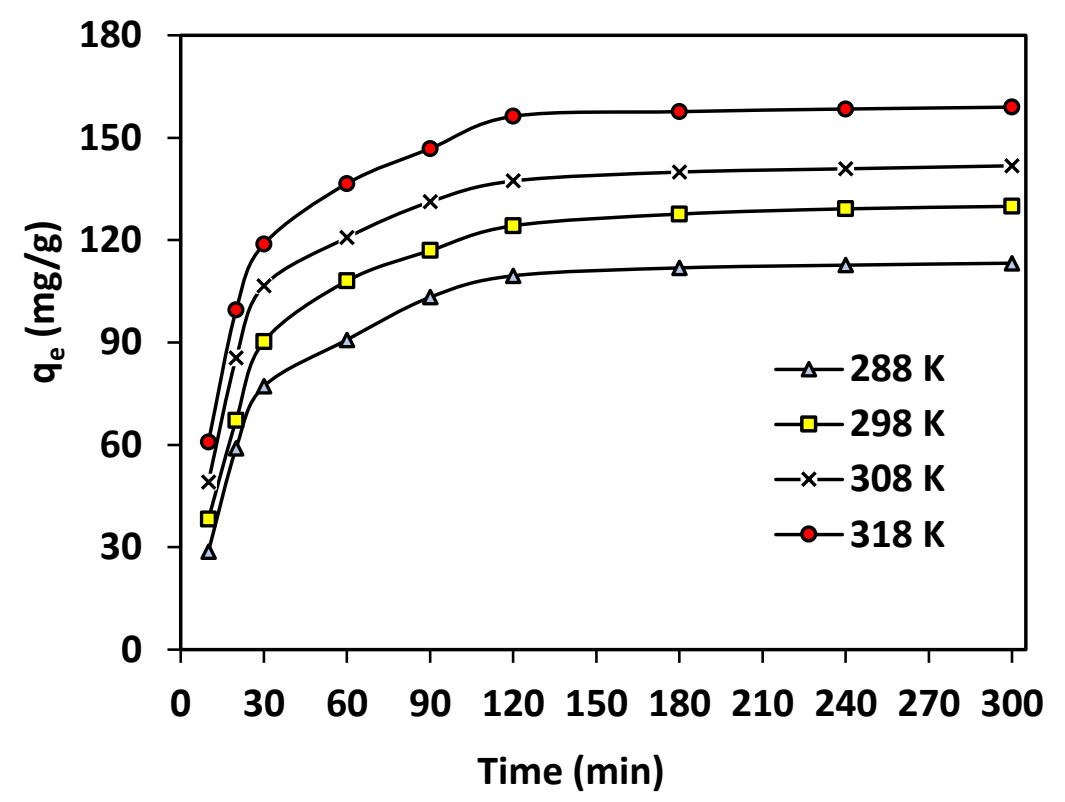

Fig. 7. Effects of temperature on the $\mathrm{AB} 113$ dye removal efficiency by $\mathrm{C}-\mathrm{Fe}_{2} \mathrm{O}_{3}(\mathrm{pH}=3$; $\mathrm{C}-$ $\mathrm{Fe}_{2} \mathrm{O}_{3}$ dose $=0.6 \mathrm{~g} / \mathrm{L} ; \mathrm{AB} 113$ dye concentration $=10 \mathrm{mg} / \mathrm{L} ;$ and adsorption time $\left.=0-300 \mathrm{~min}\right)$

Table 4. Thermodynamic parameters for the adsorption process of $\mathrm{AB} 113$ dye on $\mathrm{C}-\mathrm{Fe}_{2} \mathrm{O}_{3}$

\begin{tabular}{llll}
\hline$T(\mathrm{~K})$ & $\Delta G^{o}(\mathrm{~kJ} / \mathrm{mol})$ & $\Delta H^{o}(\mathrm{~kJ} / \mathrm{mol})$ & $\Delta S^{o}(\mathrm{~kJ} / \mathrm{mol} \cdot \mathrm{K})$ \\
\hline 288 & -2.78 & 50.20 & 0.182 \\
298 & -3.92 & & \\
308 & -5.25 & & \\
318 & -8.51 & & \\
\hline
\end{tabular}

\subsection{Regeneration study}

In the present study, the recyclability of $\mathrm{C}-\mathrm{Fe}_{2} \mathrm{O}_{3}$ was examined for six consecutive $\mathrm{AB} 113$ dye adsorption-desorption cycles under the following optimal conditions: $\mathrm{pH}=3$; $\mathrm{C}-\mathrm{Fe}_{2} \mathrm{O}_{3}$ dose $=$ 
$0.6 \mathrm{~g} / \mathrm{L} ;$ AB113 dye concentration $=10 \mathrm{mg} / \mathrm{L}$; adsorption time $=120 \mathrm{~min}$; and temperature = $25 \pm 2{ }^{\circ} \mathrm{C}$. The spent quantity of $\mathrm{C}-\mathrm{Fe}_{2} \mathrm{O}_{3}$ was separated from the aqueous solution using a magnet, rinsed with ethanol and deionized water, dried at $75^{\circ} \mathrm{C}$ for $4 \mathrm{~h}$, and then reused in the next AB113 dye adsorption cycle. The results of this experiment are presented in Fig. 8, revealing that $\mathrm{C}-\mathrm{Fe}_{2} \mathrm{O}_{3}$ can be recycled six times to adsorb $\mathrm{AB} 113$ dye. This figure also demonstrates that the removal efficiency of $\mathrm{AB} 113$ dye decreases by only $7 \%$ from the $1^{\text {st }}$ to the $6^{\text {th }}$ adsorption cycle. This decrease may be because of the loss of the adsorption ability of C$\mathrm{Fe}_{2} \mathrm{O}_{3}$ due to the washing process (Osma et al., 2007). Based on these findings, it can be concluded that $\mathrm{C}-\mathrm{Fe}_{2} \mathrm{O}_{3}$ has an excellent shelf life for use in an $\mathrm{AB} 113$ dye adsorption treatment system.

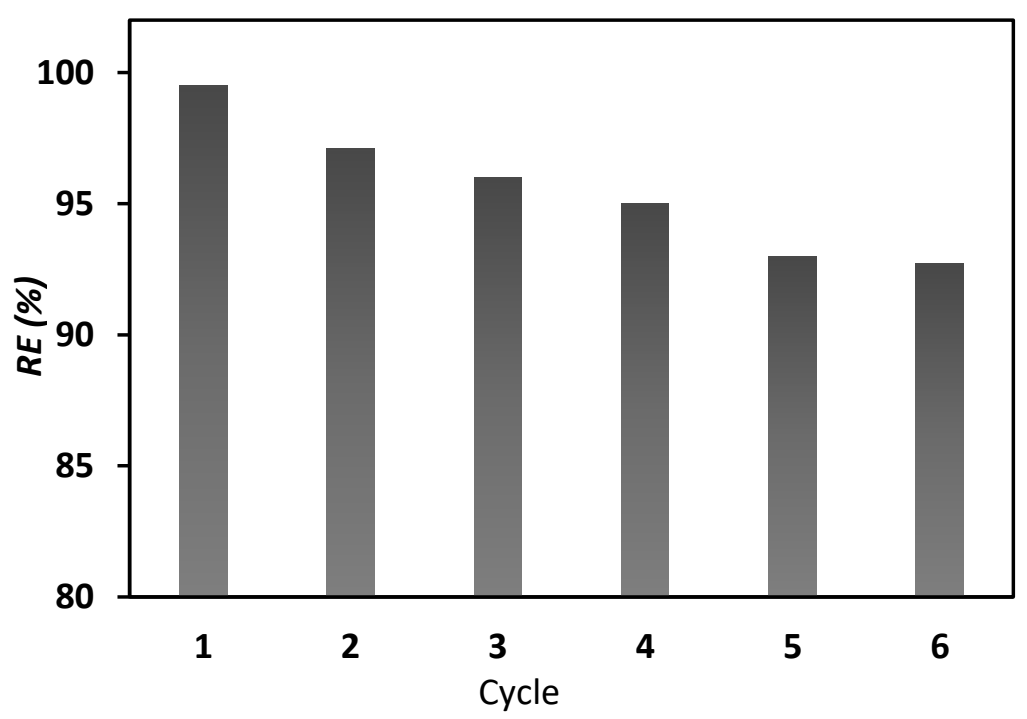

Fig. 8. Regeneration analysis of $\mathrm{C}-\mathrm{Fe}_{2} \mathrm{O}_{3}$ used for six consecutive $\mathrm{AB} 113$ dye adsorptiondesorption cycles 


\section{Conclusion}

The current work represents the first study on the application of chitosan magnetized by $\mathrm{Fe}_{2} \mathrm{O}_{3}$ nanoparticles $\left(\mathrm{C}-\mathrm{Fe}_{2} \mathrm{O}_{3}\right)$ for removing acid blue 113 (AB113) dye from aqueous solutions. Characterization analyses using advanced techniques, including SEM/EDX, TEM, XRD, FTIR, TGA, BET, and $\mathrm{pH}_{\mathrm{pzc}}$, revealed that the adsorptive specifications of chitosan, such as the surface morphology, magnetization value, and thermal stability, were greatly improved after magnetization with $\mathrm{Fe}_{2} \mathrm{O}_{3}$ nanoparticles. In addition, the 2D and 3D AFM images evidenced the adsorption phenomenon of $\mathrm{AB} 113$ dye on $\mathrm{C}-\mathrm{Fe}_{2} \mathrm{O}_{3}$. The $\mathrm{AB} 113$ dye removal efficiency was 99.68\% and occurred under the following conditions: $\mathrm{pH}=3, \mathrm{C}-\mathrm{Fe}_{2} \mathrm{O}_{3}$ dose $=0.6 \mathrm{~g} / \mathrm{L}, \mathrm{AB} 113$ dye concentration $=10 \mathrm{mg} / \mathrm{L}$, and adsorption time $=120 \mathrm{~min}$. The presence of interference ions, including $\mathrm{NaCl}, \mathrm{NaNO}_{3}, \mathrm{Na}_{2} \mathrm{CO}_{3}$, and $\mathrm{MgSO}_{4}$, led to a negative effect on the $\mathrm{AB} 113$ dye removal efficiency but at different levels. The kinetic data obtained at different AB113 dye concentrations $(10,25,50$, and $100 \mathrm{mg} / \mathrm{L})$ were consistent with the pseudo-second-order model. Based on the determined statistical goodness values of nonlinear fitting, the experimental data relevant to the isotherm and kinetic studies could be represented by the Freundlich and pseudosecond-order kinetic equations, respectively. In addition, the determined values of the thermodynamic parameters (positive $\Delta \mathrm{H}^{\mathrm{o}}$ and $\Delta \mathrm{S}^{\mathrm{o}}$ values and negative $\Delta \mathrm{G}^{\mathrm{o}}$ values) indicated that the process of $\mathrm{AB} 113$ dye adsorption on $\mathrm{C}-\mathrm{Fe}_{2} \mathrm{O}_{3}$ was favorable, spontaneous, and endothermic. Compared with other adsorbents used for dye removal, it was shown that $\mathrm{C}-\mathrm{Fe}_{2} \mathrm{O}_{3}$ was an efficacious adsorbent and good alternative for treating wastewater containing $\mathrm{AB} 113$ dye in acidic media. Additionally, $\mathrm{C}-\mathrm{Fe}_{2} \mathrm{O}_{3}$ could be recycled for six consecutive AB113 dye adsorption-desorption cycles with little loss in its efficacy. The key finding of this study was that 
$\mathrm{C}-\mathrm{Fe}_{2} \mathrm{O}_{3}$ has a high ability to remove $\mathrm{AB} 113$ dye from aqueous solutions; thus, it has potential for possible application in tertiary treatment units of dye effluents.

\section{Acknowledgments}

The authors are grateful to the Zahedan University of Medical Sciences (Iran) for the laboratory assistance and financial support of this research.

\section{Declaration of competing interest}

There are no conflicts of interest to declare.

\section{References}

Ajbary M, Santos A, Morales-Flórez V, Esquivias L. (2013). Removal of basic yellow cationic dye by an aqueous dispersion of Moroccan stevensite, Appl. Clay Sci. 80-81; 46-51.

Akar T, Celik S, Akar S. T. (2010). Biosorption performance of surface modified biomass obtained from Pyracantha coccinea for the decolorization of dye contaminated solutions. Chem. Eng. J. 160, 466-472.

Akar T, Ozcan A. S, Tunali S, Ozcan A. (2008). Biosorption of a textile dye (Acid Blue 40) by cone biomass of Thuja orientalis: estimation of equilibrium, thermodynamic and kinetic parameters. Bioresour. Technol. 99, 3057-3065.

Al-Musawi T.J, Brouers, F, Zarrabi M. What can the use of well-defined statistical functions of pollutants sorption kinetics teach us? A case study of cyanide sorption onto LTA zeolite nanoparticles. Environ. Technol. Innovation, 10, 46-54.

Anirudhan T. S, Suchithra P. S, Radhakrishnan P. G. (2009). Synthesis and characterization of humic acid immobilized-polymer/bentonite composites and their ability to adsorb basic dyes from aqueous solutions, Appl. Clay Sci. 43; 336-342.

Arami M, Limaee N. Y, Mahmoodi N. M, Tabrizi N. S. (2006). Equilibrium and kinetics studies for the adsorption of direct and acid dyes from aqueous solution by soy meal hull. J. Hazard. Mater. 135, 171-179.

Balarak D, Azarpira H. (2016). Biosorption of Acid Orang 7 using dried Cyperus Rotundus: Isotherm Studies and Error Functions. Int. J. ChemTech Res. 9; 543-549. 
Balarak D, Mahdavi Y, Bazrafshan E, Mahvi AH. (2016). Kinetic, isotherms and thermodynamic modeling for adsorption of acid blue 92 from aqueous solution by modified azolla filicoloides. Fresen Environ Bull. 25(5); 1321-30.

Balarak D, Mostafapour F. K. (2018). Adsorption of acid red 66 dye from aqueous solution by heat-treated rice husk. Res J. Chem. Environ. 2018; 22(12); 80-84.

Balarak D, Mostafapour FK, Joghataei A. (2016). Adsorption of Acid Blue 225 dye by Multi Walled Carbon Nanotubes: Determination of equilibrium and kinetics parameters. Pharm Chem, 8;138-45.

Balarak D, Abasizadeh H, Yang J. K, Shim MJ, Lee S. M. (2020). Biosorption of acid orange 7 (AO7) dye by canola waste: Equilibrium, kinetic and thermodynamics studies. Desal. Water Treat, 190, pp. 331-339.

Balarak D, Abasizdeh H, Jalalzayi Z, Rajiv P, Vanathi P. (2020). Batch adsorption of acid blue 113 dye from aqueous solution using surfactant-modified zeolite. Indian. J Environ. Prot, 40(9), 927-933.

Baskaralingam P, Pulikesi M, Elango D, Ramamurthi V, Sivanesan S. Adsorption of acid dye onto organobentonite, J. Hazard. Mater. 2006; 128; 138-144.

Bazrafshan E, Ahmadabadi A and Mahvi A. H. (2013). Reactive Red-120 removal by activated carbon obtained from cumin herb wastes. Fresen Environ Bull. 22; 584-90.

Bouatay F, Meksi N, Adeel S, Salah F, Mhenni F. (2016). dyeing behavior of the cellulosic and jute fibers with cationic dyes: process development and optimization using statistical analysis. J Nat Fiber. 13: 423-36.

Broujeni B, Nilchi A, Hassani AH Saberi R. (2018). Preparation and characterization of chitosan/ $\mathrm{Fe}_{2} \mathrm{O}_{3}$ nano composite for the adsorption of thorium (IV) ion from aqueous solution. Water Sci.Technol. 78; 708-720.

Cheung W. H, Szeto Y. S, McKay G. (2007). Intraparticle diffusion processes during acid dye adsorption onto chitosan, Bioresour. Technol. 98; 2897-2904.

Chokami M. K, Babaei L, Zamani A. A, Parizanganeh A. H. Piri F. (2017). Synthesized chitosan/iron oxide nanocomposite and shrimp shell in removal of nickel, cadmium and lead from aqueous solution. Glob. J. Environ. Sci. Manage. 3(3); 267-278.

Chu H. C, Lin L. H., Liu H. J, Chen K. M. (2013). Utilization of dried activated sludge for the removal of basic dye from aqueous solution, Desal Wat Treat. 51; 7074-80. 
Crini G, Badot PM. (2008). Application of chitosan, a natural aminopolysaccharide, for dye removal from aqueous solutions by adsorption processes using batch studies: A review of recent literature. Prog Polym Sci. 33; 399-447.

Dotto GL, Pinto LAA. Adsorption of food dyes acid blue 9 and yellow 3 onto chitosan: stirring rate effect in kinetics and mechanism. J Hazard Mater. 2011; 187:164-170.

Elgin A. B, Özdemir O, Turan M, Turan A. Z. (2008). Color removal from textile dye bath effluents in a zeolite fixed bed reactor: determination of optimum process conditions using Taguchi method, J. Hazard. Mater. 159; 348-353.

Eren E. (2010). Adsorption performance and mechanism in binding of azo dye by raw bentonite. Clean: Soil, Air, Water. 38; 758-763.

Ferrero F. (2007). Dye removal by low cost adsorbents: hazelnut shells in comparison with wood sawdust. J. Hazard. Mater. 142, 144-152.

Fiorentin L. D, Trigueros D. E. G, Pereira N. C. Barros S. T.D, Santos O. A. A. (2010). Biosorption of reactive blue $5 \mathrm{G}$ dye onto drying orange bagasse in batch system: kinetic and equilibrium modeling. Chem. Eng. J. 163, 68-77.

Fontana K. B, Chaves E. S, Sanchez J. D. S, Lenzi G. G. (2016). Textile dye removal from aqueous solutions by malt bagasse: Isotherm, kinetic and thermodynamic studies. Ecotoxicol. Environ. Saf. 124, 329-336.

Giustetto R, Wahyudi O. (2011). Sorption of red dyes on palygorskite: synthesis and stability of red/purple Mayan nanocomposites. Microporous. Mesoporous. Mater. 142; 221-235.

Gok O, Ozcan A.S, Ozcan A. (2010). Adsorption behavior of a textile dye of Reactive Blue 19 from aqueous solutions onto modified bentonite. Appl. Surf. Sci. 256, 5439-43.

Gupta A. K, Gupta M. (2005). Synthesis and surface engineering of iron oxide nanoparticles for biomedical applications. Biomaterials. 26; 3995-4021.

Hameed B.H, Hakimi H. (2008). Utilization of durian (Durio zibethinus Murray) peel as low cost sorbent for the removal of acid dye from aqueous solutions. Biochem. Eng. J. 39, 338343.

Han R, Zhang J, Han P, Wang Y. (2009). Study of equlibrium, kinetic and thermodynamic parameters about methylene blue adsorption onto natural zeolite. Chem Eng. J. 145; 496-504. 
Hao Y, Yan L, Yu H, Yang K, Yu S, Shan R. L. (2014). Comparative study on adsorption of basic and acid dyes by hydroxy-aluminum pillared bentonite, J. Mol. Liq. 199; 202207.

Hilal N. M, Ahmed I. A, Badr E. E. (2012). Removal of acid dye (AR37) by adsorption onto potatoes and egg husk: a comparative study. J American Sci. 8; 341-348.

Hu Z, Chen H, Ji F. (2015). Removal of Congo red from aqueous solution by cattail root. J. Hazard. Mater. 173: 292-297.

Huang R, Wang B, Yang B, Zheng D. (2011). Equilibrium, kinetic and thermodynamic studies of adsorption of Cd (II) from aqueous solution onto HACC-bentonite. Desalination. 280; 297-304.

Joshi S, Garg, V, Kataria, N, Kadirvelu K. (2019). Applications of $\mathrm{Fe}_{3} \mathrm{O} @$ AC nanoparticle for dye removal from simulated wastewater. Chemosphere. 236; 124280.

Kavitha A. L, Prabu H. G, Babu S. A. (2012). Synthesis of low-cost Iron Oxide-Chitosan nanocomposite for antibacterial activity. Int. J. Polym. Mater. Polym. Biomat. 62; 4549.

Khandanlou R, Ahmad M. B, Shameli K, Kalantari K. (2013). Synthesis and characterization of Rice straw/ $\mathrm{Fe}_{3} \mathrm{O}_{4}$ nanocomposite by a quick precipitation method. Molecules. 18; 65976607.

Khodadadi M, Al-Musawi T. J, Kamranifar M. Saghi M. H. \& Panahi, A. H. (2019). A comparative study of using barberry stem powder and ash as adsorbents for adsorption of humic acid. Environ. Sci. Pollut. Res. 26; 26159-26169.

Kyzas G. Z, Deliyanni E. A. (2013). Mercury(II) removal with modified magnetic chitosan adsorbents. Molecules. 18; 6193-6214.

Lakshmi U. R, Srivastava V. C, Mall I. D, Lataye D. H. (2009). Rice husk ash as an effective adsorbent: evaluation of adsorptive characteristics for Indigo Carmine dye. J. Environ. Manag. 90; 710-720.

Li Q, Yue QY, Su Y, Gao B. Y, Sun H. J. (2010). Equilibrium, thermodynamics and process design to minimize adsorbent amount for the adsorption of acid dyes onto cationic polymer-loaded bentonite, Chem. Eng. J. 158; 489-497.

Ma J, Cui B, Dai J, Li D. (2011). Mechanism of adsorption of anionic dye from aqueous solutions onto organobentonite, J. Hazard. Mater. 186; 1758-1765. 
Madrakian T, Afkhami A, Ahmadi M, Bagheri H. (2011). Removal of some cationic dyes from aqueous solutions using magnetic-modified multi-walled carbon nanotubes. J. Hazard. Mater. 196: 109-14.

Meziti C, Boukerroui A. (2012). Removal of a Basic Textile Dye from Aqueous Solution by Adsorption on Regenerated Clay. Procedia Engineering. 33; 303-312.

Mittal H, Mishra S. B. (2014). Gum ghatti and $\mathrm{Fe}_{3} \mathrm{O}_{4}$ magnetic nanoparticles based nanocomposites for the effective adsorption of rhodamine B. Carbohydr. Polym. 101; $1255-1264$.

Mohammed A. A, Najim A. A, Al-Musawi T. J, Alwared A. I. (2019) Adsorptive performance of a mixture of three nonliving algae classes for nickel remediation in synthesized wastewater. J Environ. Health. Sci. Eng. 17; 529-538

Nasseh N, Khosravi R, Rumman G. A, Ghadirian M, Eslami H, Khoshnamvand M, Al-Musawi T. J. \& Khosravi A. (2021). Adsorption of $\mathrm{Cr}(\mathrm{VI})$ ions onto powdered activated carbon synthesized from Peganum harmala seeds by ultrasonic waves activation. Environ. Technol. Innovation. 21, 101277.

Osma J. F, Saravia V, Toca-Herrera J. L, Couto S. R. (2007). Sunflower seed shells: A novel and effective low-cost adsorbent for the removal of the diazo dye Reactive Black 5 from aqueous solutions. J. Hazard. Mater. 147; 900-905.

Rostamian, R. \& Behnejad, H. (2016). A comparative adsorption study of sulfamethoxazole onto graphene and graphene oxide nanosheets through equilibrium, kinetic and thermodynamic modeling. Process Saf. Environ. Prot. 102; 20-29.

Samarghandi M, Al-Musawi T, Mohseni-Bandpi A, Zarrabi M. (2015). Adsorption of cephalexin from aqueous solution using natural zeolite and zeolite coated with manganese oxide nanoparticles. J. Mo. Liq. 211; 431-441.

Sanghi R, Verma P. (2013). Decolorisation of aqueous dye solutions by low-cost adsorbents: a review. Color. Technol. 129; 85-108.

Savic I, Gajic D, Stojiljkovic S, Savic I. (2014). Modeling and optimization of methylene blue adsorption from aqueous solution using bentonite clay, Comput. Aided. Chem. Eng. 33; $1417-1422$.

Shan R, Yan L, Yang Y, Yang K, Yu S, Yu H. (2015). Highly efficient removal of three red dyes by adsorption onto Mg-Al-layered double hydroxide, J. Ind. Eng. Chem. 21; 561-568. 
Sillanpää M, Mahvi A. H. (2021). Adsorption of Acid orange 7 dyes from aqueous solution using Polypyrrole/nanosilica composite: Experimental and modelling. Inter. J. Environ. Anal. Chem. 2021.

Somasekhara R, Sivaramakrishna M.C, Varada R. (2012). The use of an agricultural waste material, Jujuba seeds for the removal of anionic dye (Congo red) from aqueous medium. J. Hazard. Mater. 203-204, 118-127.

Sun X, Peng B, Ji Y, Chen J, Li D. (2009). Chitosan(chitin)/cellulose composite biosorbents prepared using ionic liquid for heavy metal ions adsorption. AlChE. 55; 2062-2069.

Suna D, Zhanga X, Wub Y, Liu X. (2010). Adsorption of anionic dyes from aqueous solution on fly ash. J. Hazard. Mater. 181, 335-342.

Tabak A, Baltas N, Afsin B, Emirik M, Caglar B, Eren E. (2010). Adsorption of Reactive Red 120 from aqueous solutions by cetylpyridinium-bentonite. J. Chem. Technol. Biotechnol. 85; 1199-1207.

Wu P, Wu T, He W, Sun L, Li Y. (2013). Adsorption properties of dodecylsulfateintercalated layered double hydroxide for various dyes in water, Colloids. Surf. A Physicochem. Eng. Asp. 436; 726-731.

Xua L, Wang J. (2012). Fenton-like degradation of 2, 4-dichlorophenol using $\mathrm{Fe}_{3} \mathrm{O}_{4}$ magnetic nanoparticles. Appl. Catal. B: Environ. 123-124; 117-126.

Yao Y, Xu F, Chen M, Xu Z, Zhu Z. (2010). Adsorption behavior of methylene blue on carbon nanotubes. Bioresour Technol. 101; 3040-3046.

Zazouli M. A, Cherati J. Y. Ebrahimi M, Mahdavi Y. (2013). Investigating the removal rate of acid blue 113 from aqueous solution by canola (Brassica Napus). J. Mazand. Uni. Med. Sci. 22; 70-78.

Zhang Y. J, Liu L. C, Ni L. L, Wang B. L. (2013). A facile and low-cost synthesis of granulated blast furnace slag-based cementitious material coupled with $\mathrm{Fe}_{2} \mathrm{O}_{3}$ catalyst for treatment of dye wastewater, Appl. Catal. B. Environ. 138-139; 9-16. 


\section{Figures}
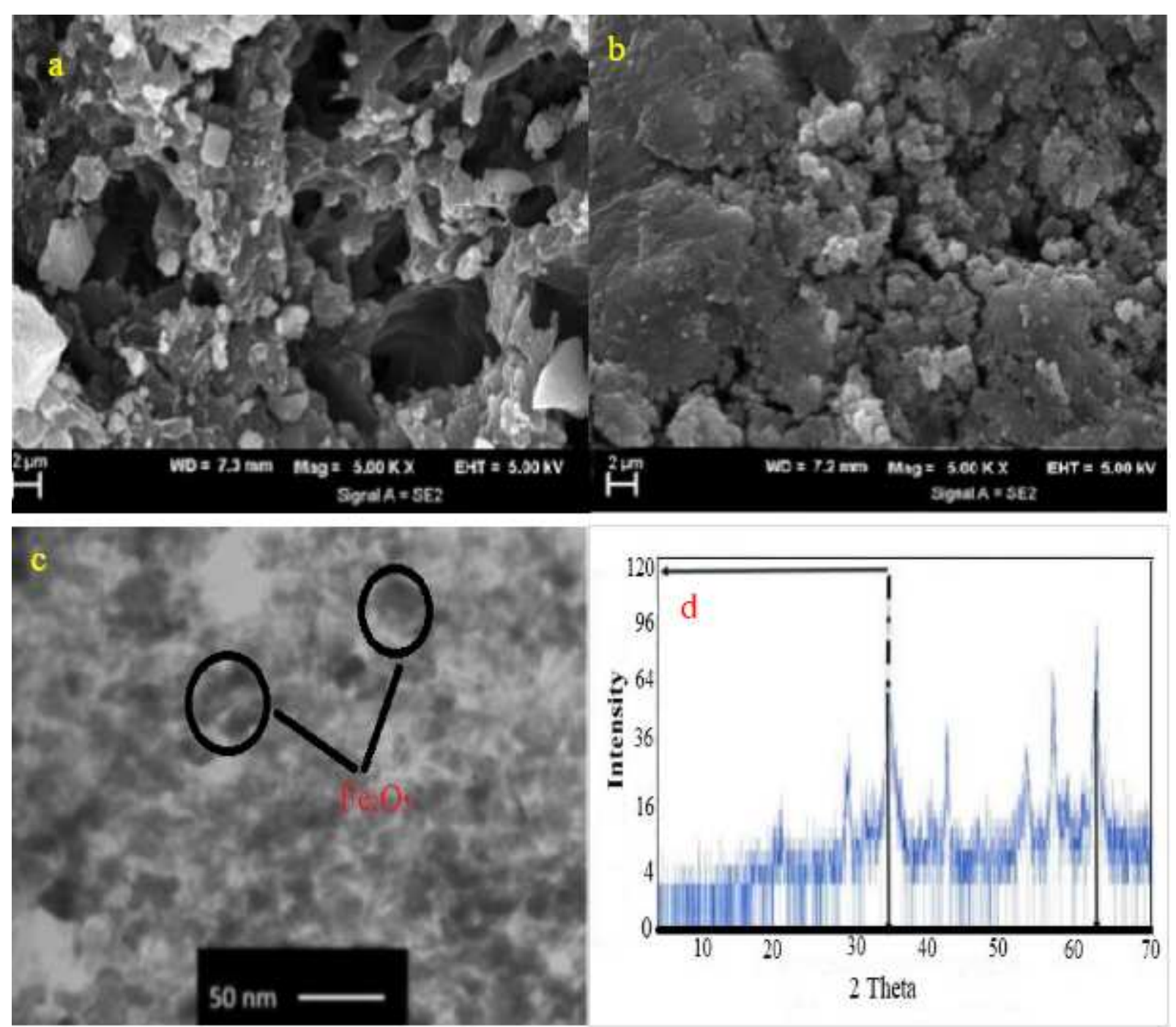

\section{Figure 1}

SEM images of C-Fe2O3 before (a) and after (b) AB113 adsorption. TEM image of C-Fe2O3 (c). X-ray diffraction pattern of C-Fe203 (d). 
A

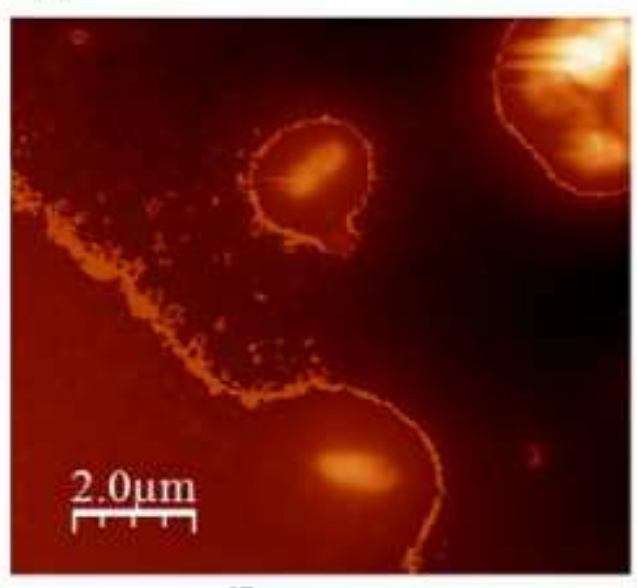

2D

B

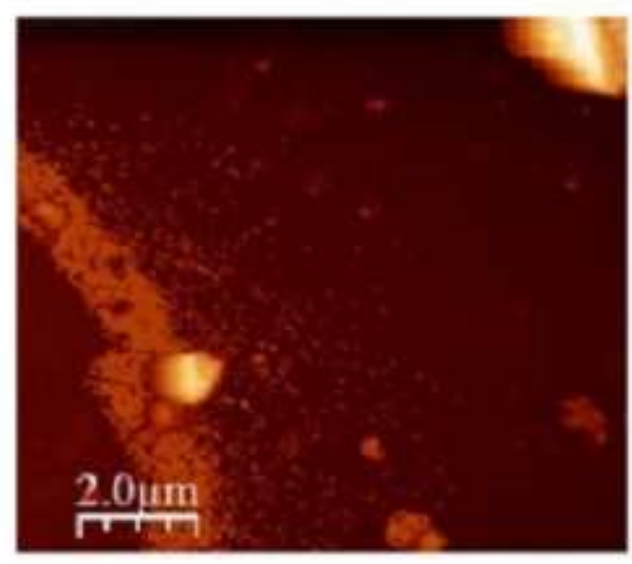

2D
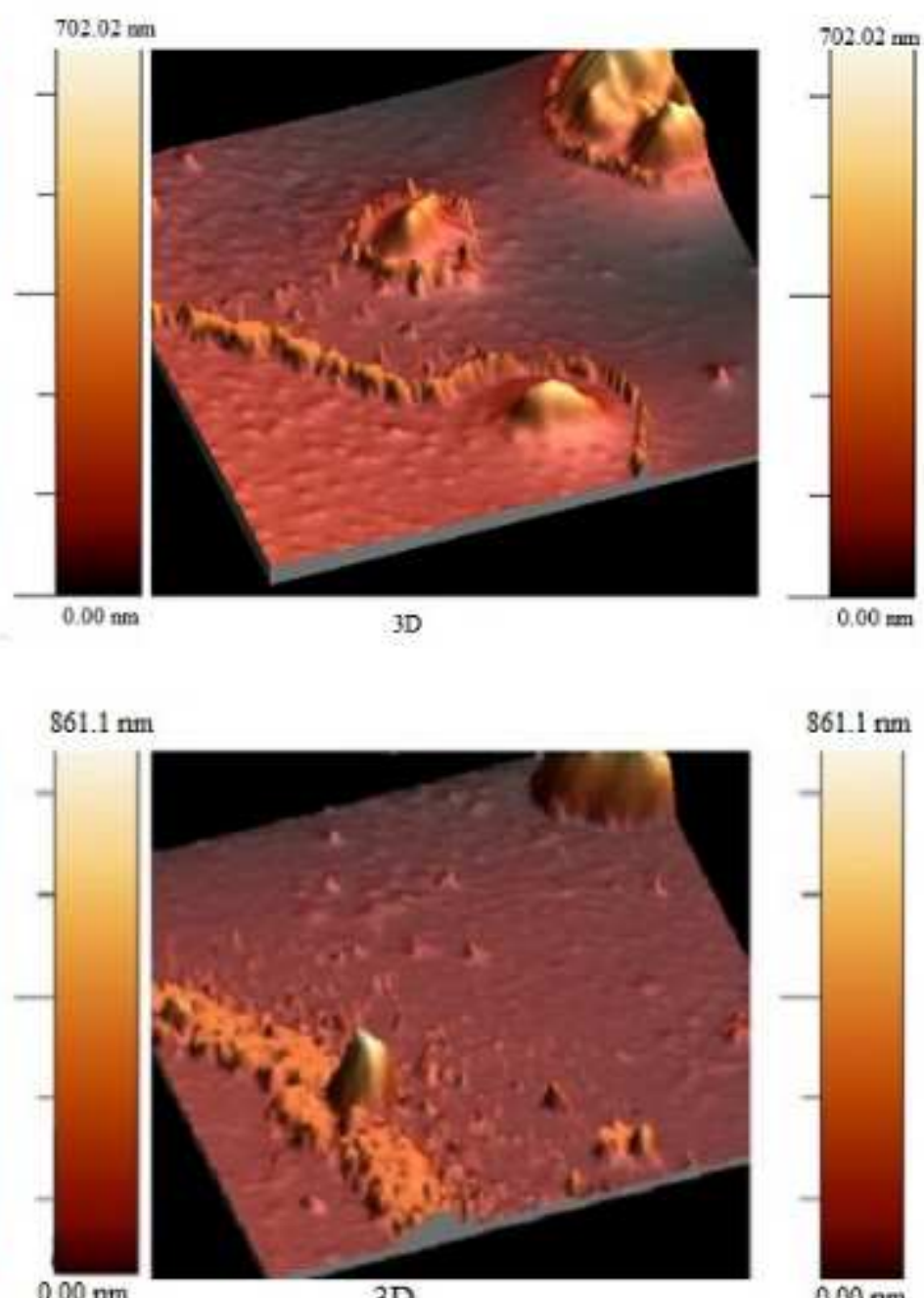

3D
$861.1 \mathrm{~nm}$

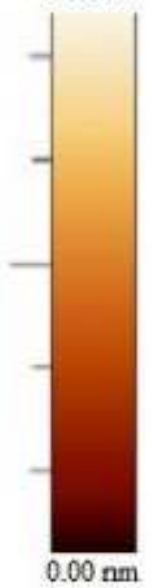

Figure 2

2D and 3D AFM images of C-Fe2O3 before (A) and after (B) adsorption of AB113 dye. 

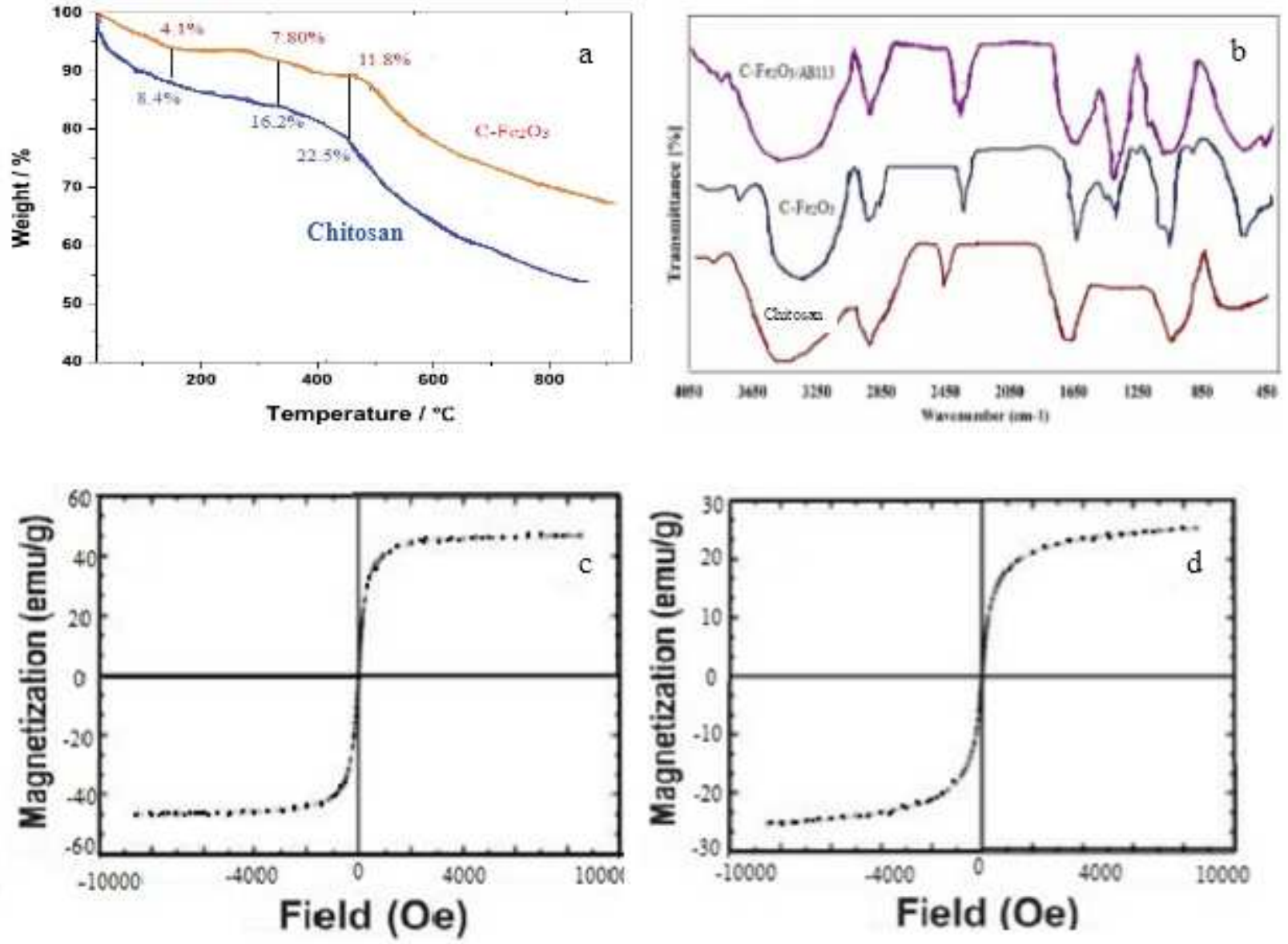

Field (Oe)

Figure 3

TGA graph of chitosan and C-Fe203 (a). FTIR spectra of chitosan, C-Fe2O3 and C-Fe2O3 after reaction with the AB113 dye (C-Fe2O3/AB113) (b). Magnetization curves of the Fe2O3 nanoparticles (c) and C$\mathrm{Fe} 2 \mathrm{O} 3(\mathrm{~d})$. 

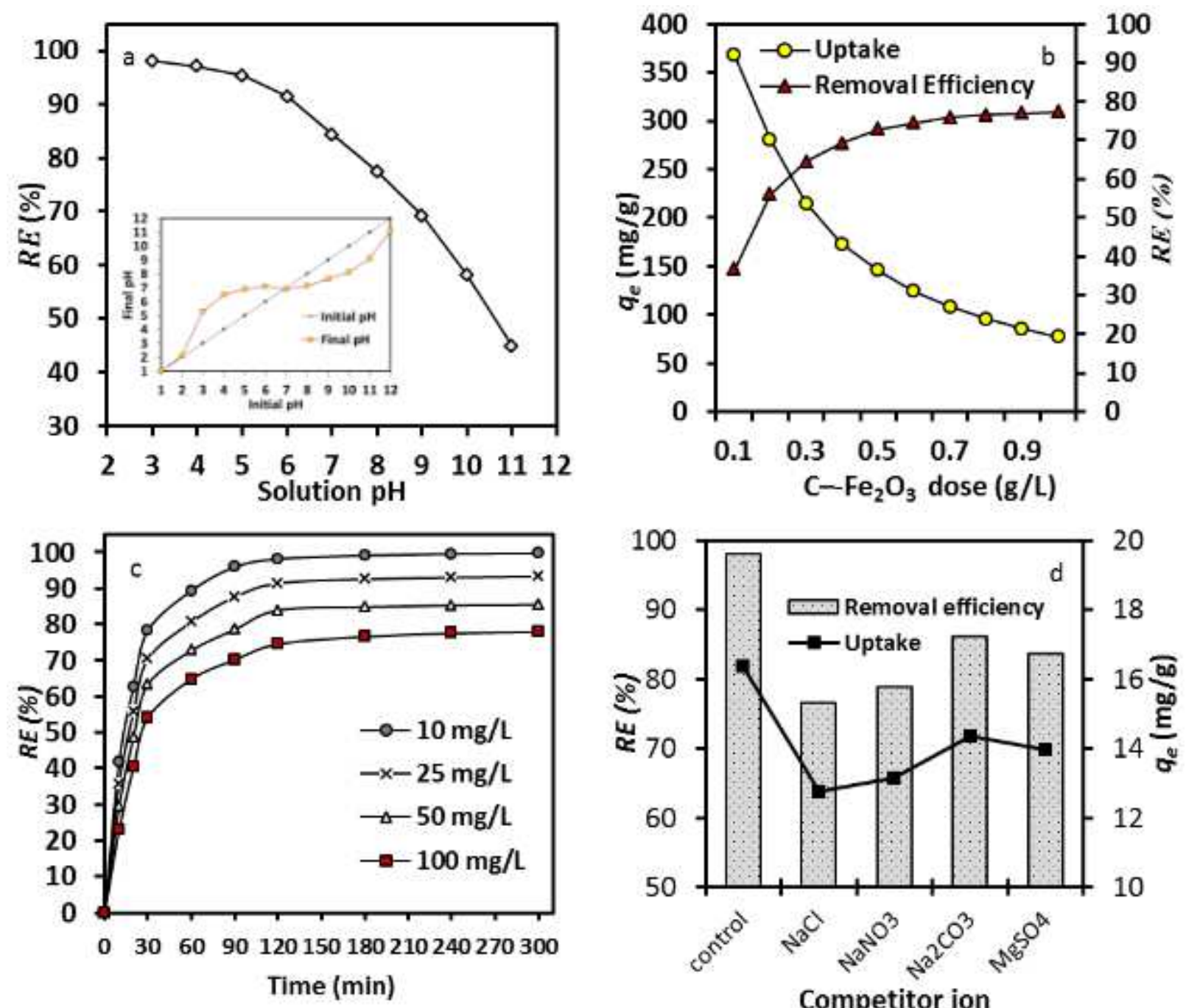

Figure 4

Effect study of pH and the pHpzc analysis (a), C-Fe2O3 dose (b), Initial Ab113 dye concentration (c), and Interference ions (d). 


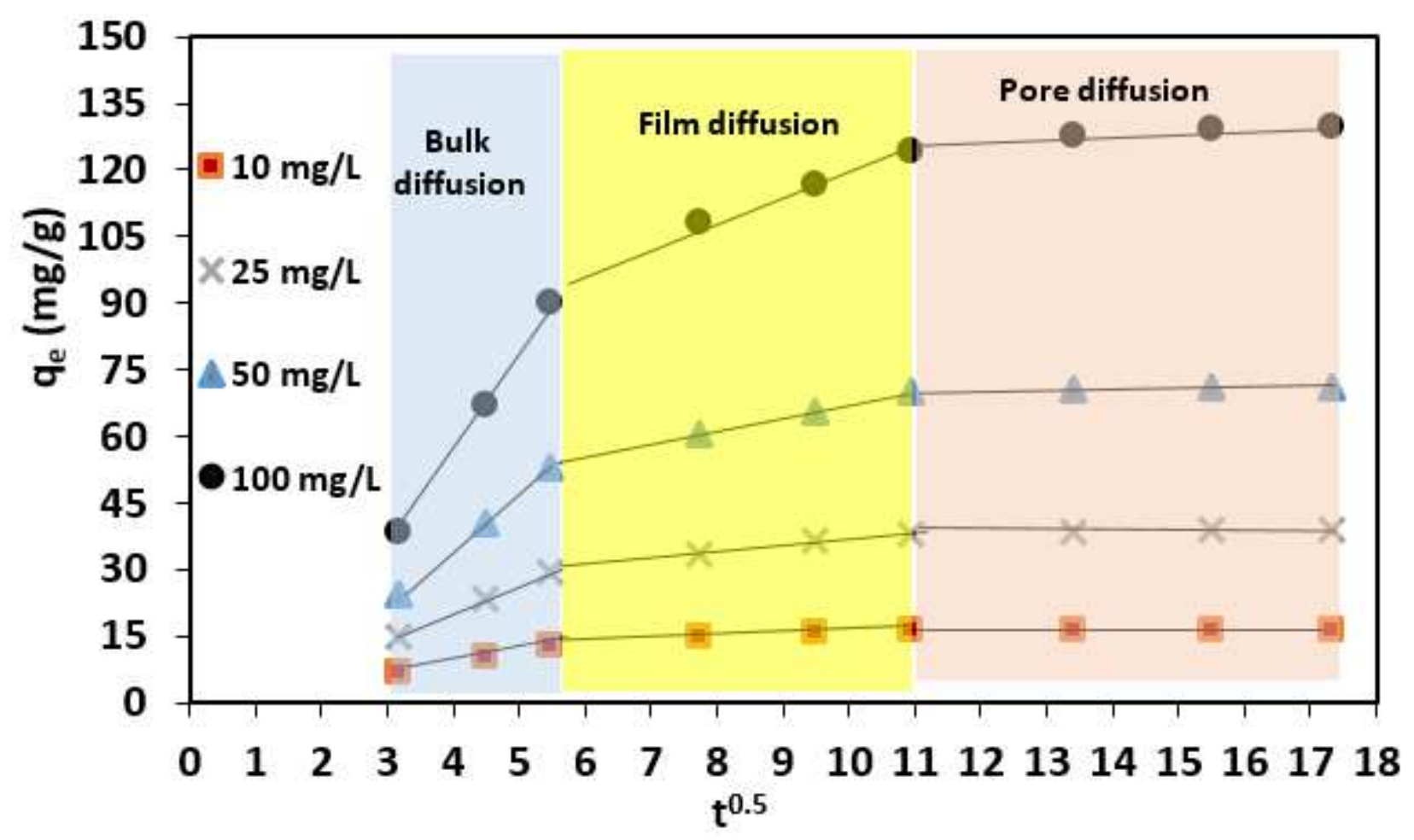

Figure 5

Three stages of the kinetics adsorption of AB113 onto C-Fe2O3.

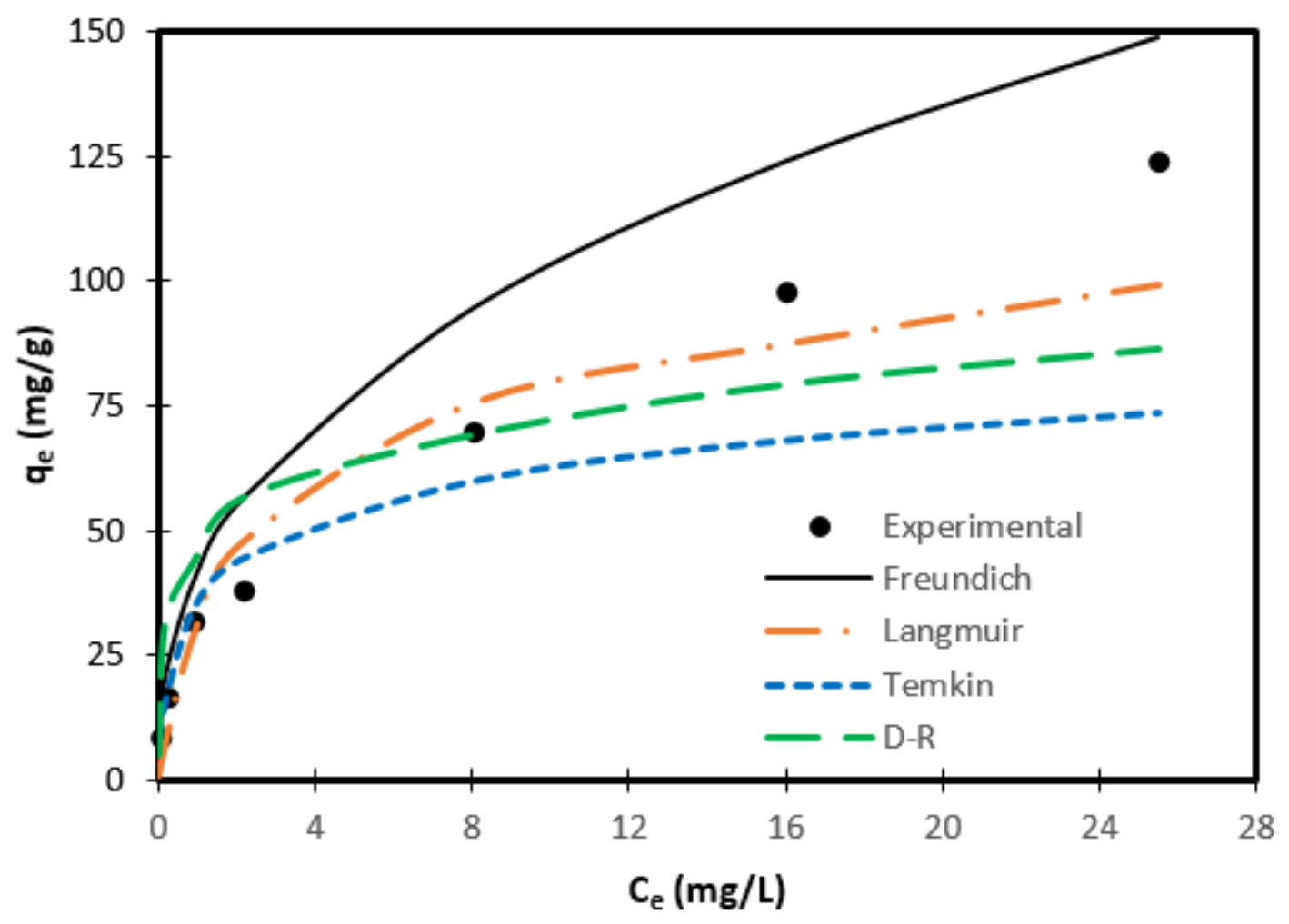

Figure 6 
Experimental and theoretical isothermal data of AB113 dye adsorption on C-Fe2O3.

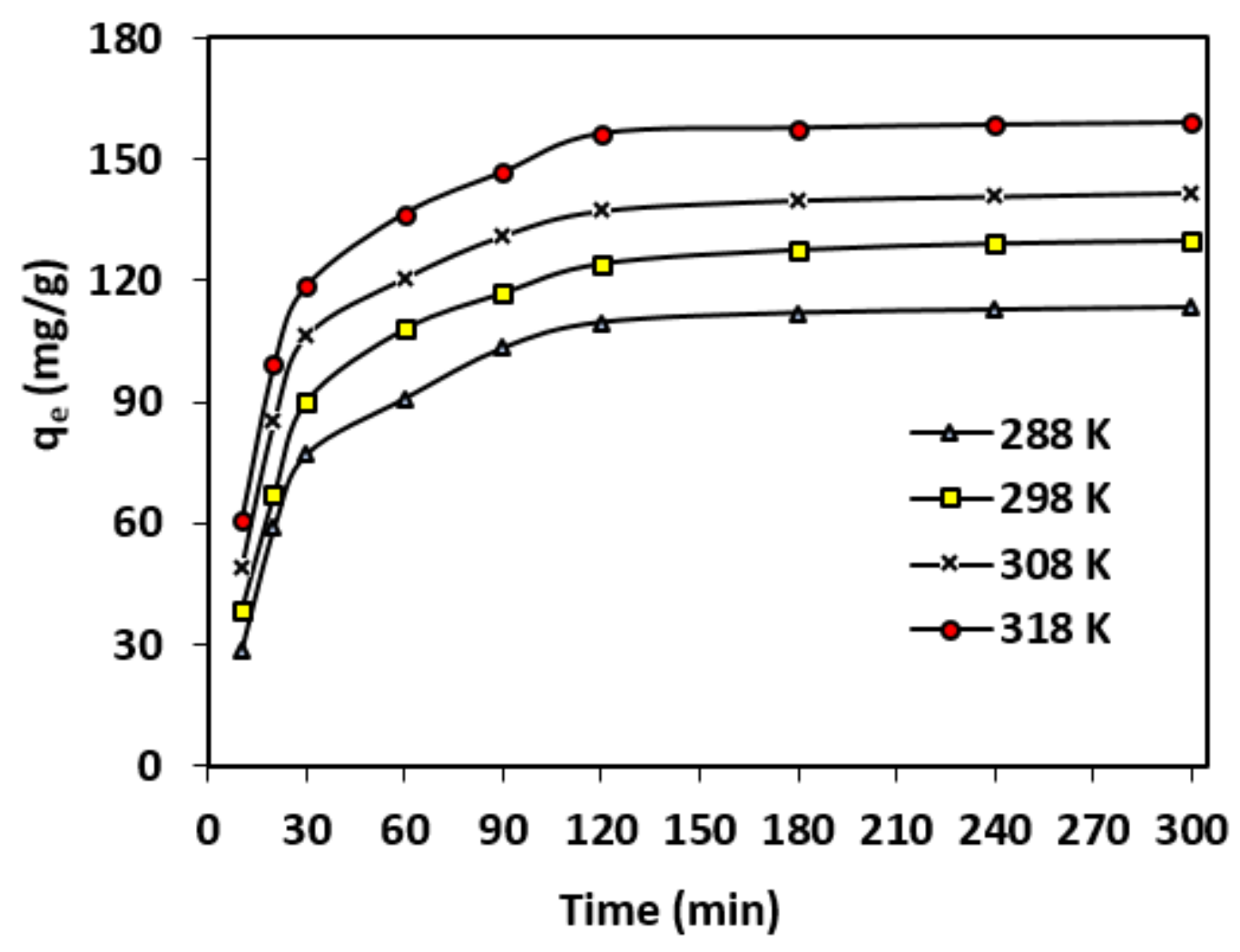

Figure 7

Effects of temperature on the AB113 dye removal efficiency by C-Fe2O3 $(\mathrm{pH}=3 ; \mathrm{C}-\mathrm{Fe} 2 \mathrm{O} 3$ dose $=0.6$ $\mathrm{g} / \mathrm{L} ; \mathrm{AB} 113$ dye concentration $=10 \mathrm{mg} / \mathrm{L}$; and adsorption time $=0-300 \mathrm{~min}$ )

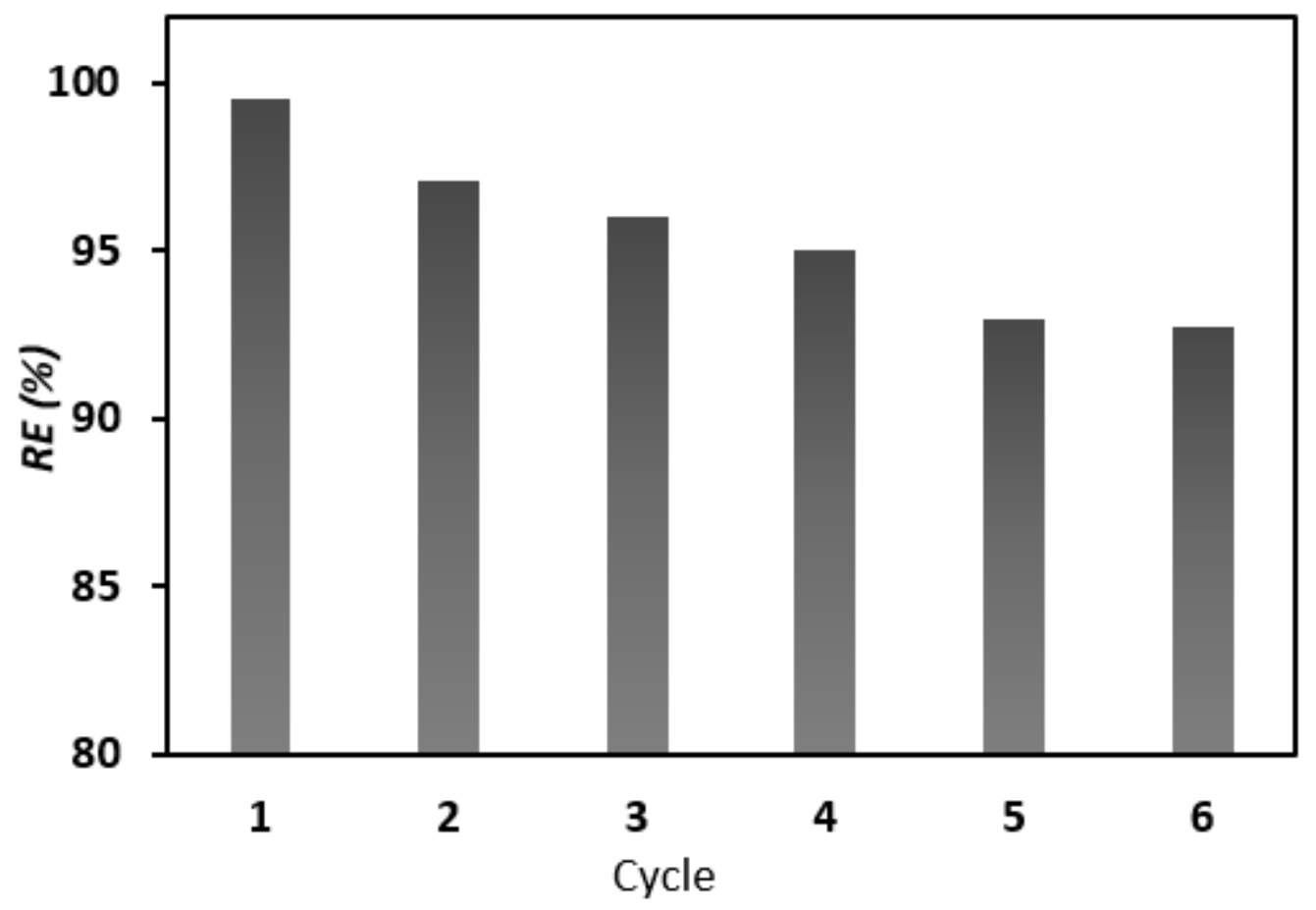


Figure 8

Regeneration analysis of C-Fe2O3 used for six consecutive AB113 dye adsorption-desorption cycles

\section{Supplementary Files}

This is a list of supplementary files associated with this preprint. Click to download.

- graphicalabstract.jpg 